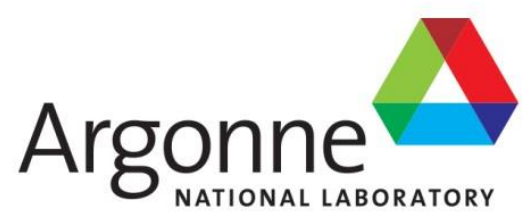

\title{
Lifecycle Analysis of Renewable Natural Gas and Hydrocarbon Fuels from Wastewater Treatment Plants' Sludge
}

Energy Systems Division 


\begin{abstract}
About Argonne National Laboratory
Argonne is a U.S. Department of Energy laboratory managed by UChicago Argonne, LLC under contract DE-AC02-06CH11357. The Laboratory's main facility is outside Chicago, at 9700 South Cass Avenue, Argonne, Illinois 60439. For information about Argonne and its pioneering science and technology programs, see www.anl.gov.
\end{abstract}

\title{
DOCUMENT AVAILABILITY
}

Online Access: U.S. Department of Energy (DOE) reports produced after 1991 and a growing number of pre-1991 documents are available free via DOE's SciTech Connect (http://www.osti.gov/scitech/).

Reports not in digital format may be purchased by the public from the National Technical Information Service (NTIS):

U.S. Department of Commerce

National Technical Information Service

5301 Shawnee Rd

Alexandria, VA 22312

unw.ntis.gov

Phone: (800) 553-NTIS (6847) or (703) 605-6000

Fax: (703) 605-6900

Email: orders@ntis.gov

Reports not in digital format are available to DOE and DOE contractors from the Office of Scientific and Technical Information (OST):

U.S. Department of Energy

Office of Scientific and Technical Information

P.O. Box 62

Oak Ridge, TN 37831-0062

unw.osti.gov

Phone: (865) 576-8401

Fax: (865) 576-5728

Email: reports@osti.gov

\section{Disclaimer}

This report was prepared as an account of work sponsored by an agency of the United States Government. Neither the United States Government nor any agency thereof, nor UChicago Argonne, LLC, nor any of their employees or officers, makes any warranty, express or implied, or assumes any legal liability or responsibility for the accuracy, completeness, or usefulness of any information, apparatus, product, or process disclosed, or represents that its use would not infringe privately owned rights. Reference herein to any specific commercial product, process, or service by trade name, trademark, manufacturer, or otherwise, does not necessarily constitute or imply its endorsement, recommendation, or favoring by the United States Government or any agency thereof. The views and opinions of document authors expressed herein do not necessarily state or reflect those of the United States Government or any agency thereof, Argonne National Laboratory, or UChicago Argonne, LLC. 


\section{Lifecycle Analysis of Renewable Natural Gas and Hydrocarbon Fuels from Wastewater Treatment Plants' Sludge}

by

Uisung Lee, Jeongwoo Han, Meltem Urgun Demirtas, Michael Wang; Argonne National Laboratory Ling Tao; National Renewable Energy Laboratory

September 2016 



\section{CONTENTS}

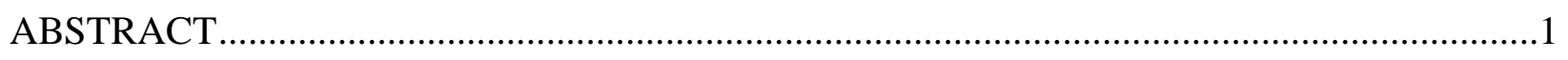

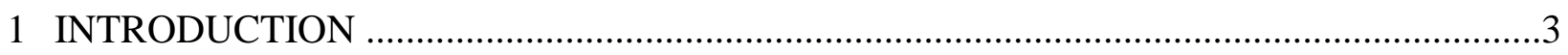

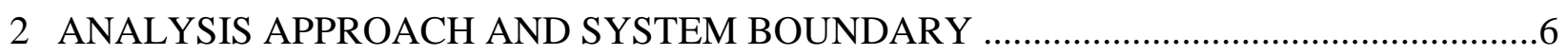

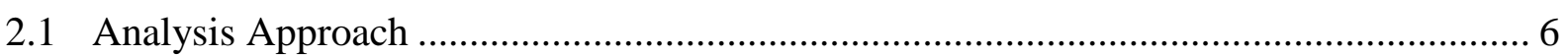

2.2 Anaerobic Digestion Pathway System Boundary ………………………………........... 8

2.3 Hydrothermal Liquefaction Pathways System Boundary ................................................ 11

3 PARAMETRIC ASSUMPTIONS OF WASTE-TO-ENERGY PATHWAYS ……….............12

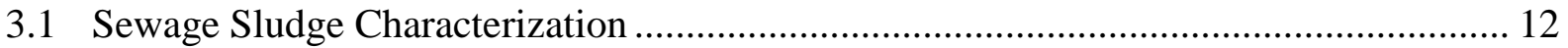

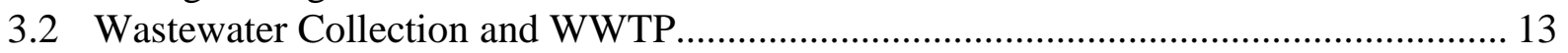

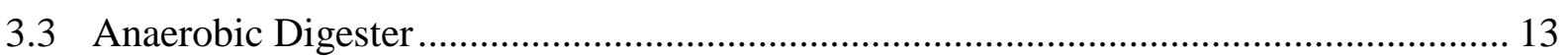

3.3.1 Semi-Empirical Model............................................................................. 13

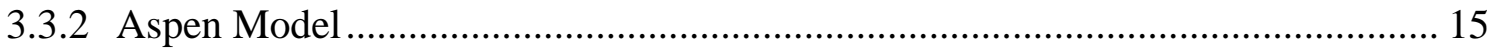

3.3.3 Digestate and Supernatant............................................................................. 17

3.3.4 Biogas Combustion and Flaring....................................................................... 18

3.3.5 Biogas Cleanup and Upgrading to CNG/LNG ................................................ 19

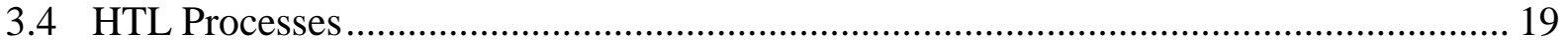

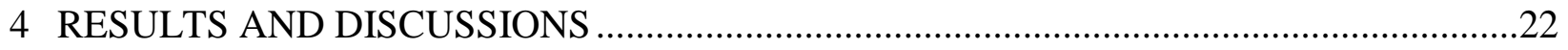

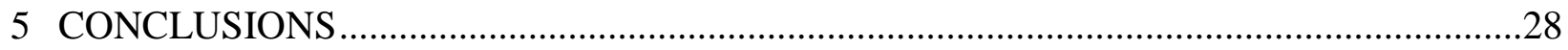

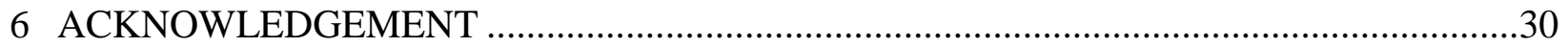

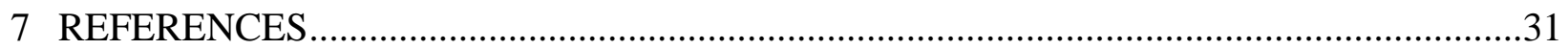

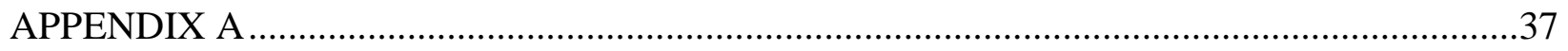

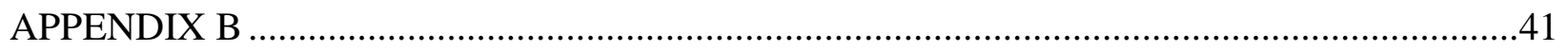

\section{FIGURES}

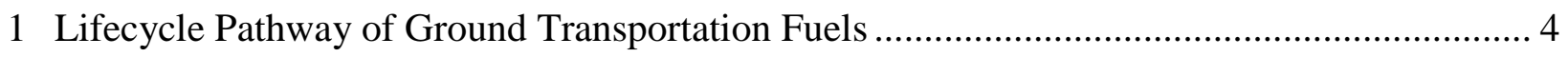

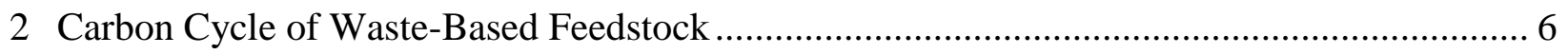

3 Counterfactual Scenario of the Fuel Production from Sewage Sludge ........................................ 8

4 WTW Pathway for Wastewater Sludge-based CNG and LNG via AD ................................... 9

5 WTW Pathway for Wastewater Sludge-based Renewable Diesel via HTL ............................. 11

6 Process Diagram of the Aspen AD Model Using Sludge ..................................................... 16

7 Process Diagram of the Aspen HTL Model using Sewage Sludge......................................... 20

8 WTW GHG Emissions for Renewable CNG from AD and Renewable Diesel from HTL Pathways Produced from Sewage Sludge (kg CO2e/dry ton of Sludge Input) ............... 23 


\section{FIGURES (CONT.)}

9 WTW GHG Emissions for CNG Produced from Sewage Sludge via AD and Renewable Diesel Produced from HTL Pathways Compared to Conventional NG,

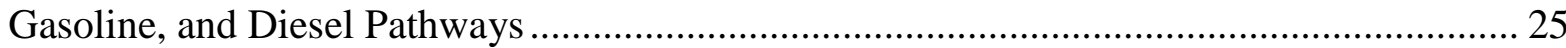

10 WTW Fossil Fuel Use for CNG Produced from Sewage Sludge via AD and Renewable Diesel Produced from HTL Pathways Compared to Conventional NG, Gasoline, and Diesel Pathways

\section{TABLES}

1 Number and Wastewater Flow of U.S. WWTP by WWTP Size ...................................... 7

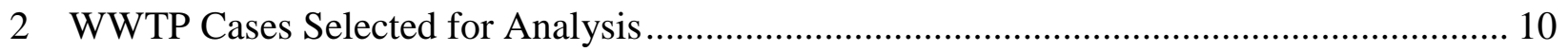

3 Characteristics and Composition of Sewage Sludge Feedstock ....................................... 12

4 Thermal Energy Requirement of Mesophilic Digesters ................................................... 14

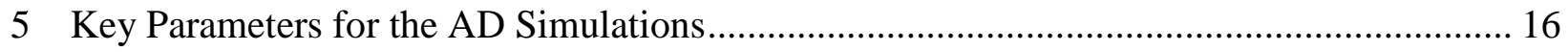

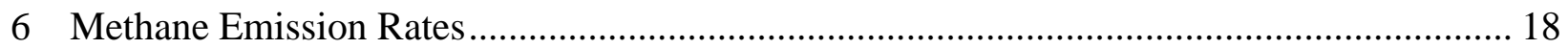

7 CHP Electrical Efficiency and Thermal Energy Recovery Factor by Prime Movers............ 19

8 Key Inputs, Outputs, and Emissions of the HTL Processes Using Sewage Sludge .............. 21

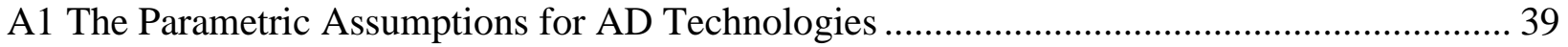

B1 Estimates of Average Electric Energy Intensity of Various Wastewater Treatment Facilities 


\title{
LIFECYCLE ANALYSIS OF RENEWABLE NATURAL GAS AND HYDROCARBON FUELS FROM WASTEWATER TREATMENT PLANTS' SLUDGE
}

\author{
Uisung Lee, Jeongwoo Han, Meltem Urgun Demirtas, and Michael Wang \\ Argonne National Laboratory \\ and \\ Ling Tao \\ National Renewable Energy Laboratory
}

\begin{abstract}
Wastewater treatment plants (WWTPs) produce sludge as a byproduct when they treat wastewater. In the United States, over 8 million dry tons of sludge are produced annually just from publicly owned WWTPs. Sludge is commonly treated in anaerobic digesters, which generate biogas; the biogas is then largely flared to reduce emissions of methane, a potent greenhouse gas. Because sludge is quite homogeneous and has a high energy content, it is a good potential feedstock for other conversion processes that make biofuels, bioproducts, and power. For example, biogas from anaerobic digesters can be used to generate renewable natural gas (RNG), which can be further processed to produce compressed natural gas (CNG) and liquefied natural gas (LNG). Sludge can be directly converted into hydrocarbon liquid fuels via thermochemical processes such as hydrothermal liquefaction (HTL). Currently, the environmental impacts of converting sludge into energy are largely unknown, and only a few studies have focused on the environmental impacts of RNG produced from existing anaerobic digesters. As biofuels from sludge generate high interest, however, existing anaerobic digesters could be upgraded to technology with more economic potential and more environmental benefits. The environmental impacts of using a different anaerobic digestion (AD) technology to convert sludge into energy have yet to be analyzed. In addition, no studies are available about the direct conversion of sludge into liquid fuels. In order to estimate the energy consumption and greenhouse gas (GHG) emissions impacts of these alternative pathways (sludge-to-RNG and sludge-to-liquid), this study performed a lifecycle analysis (LCA) using the Greenhouse gases, Regulated Emissions, and Energy use in Transportation $\left(\right.$ GREET $\left.^{\circledR}\right)$ model. The energy uses and GHG emissions associated with the RNG and hydrocarbon liquid are analyzed relative to the current typical sludge management case, which consists of a single-stage mesophilic digester with biogas flaring. Along with the alternative HTL process, four types of AD technologies with fuel production - single-stage mesophilic, mesophilic 2-stage, single-stage mesophilic with thermohydrolysis treatment, and mesophilicmesophilic acid/gas phase - are studied. Results show that the sludge-to-CNG pathway via $A D$ and the sludge-to-liquid pathway via HTL reduce GHG emissions consumptions significantly. When we compare the GHG emissions of the alternative fuel production pathways to that of the counterfactual case in terms
\end{abstract}


of the amount of sludge treated, reductions in GHG emissions are 39\%-80\% and $87 \%$ for alternative AD and HTL, respectively. Compared to petroleum gasoline and diesel GHG emission results in terms of $\mathrm{MJ}$, the renewable $\mathrm{CNG}$ production pathway via $\mathrm{AD}$ and the renewable diesel production pathway via HTL reduce GHG emissions by $193 \%$ and $46 \%$, respectively. These large reductions are mainly due to GHG credits from avoiding GHGs under the counterfactual scenario, and/or fertilizer displacement credits. Similarly, reductions in fossil fuel use for sludge-based fuels are huge. However, well-defined counterfactual scenarios are needed because the results of the study depend on the counterfactual scenario, which might vary over time. 


\section{INTRODUCTION}

A large amount of waste material is generated in the United States. For example, the amount of sludge from wastewater treatment plants (WWTPs) and municipal solid waste (MSW) generated annually is estimated at 8 and 77 million dry tons, respectively (EPA 2015, 2006a). This waste generates a significant amount of greenhouse gas (GHG) directly (e.g., as fugitive methane emissions from organic waste) and through their treatment processes (e.g., flaring raw bio-methane). The U.S. Environmental Protection Agency (EPA) estimated that 165 million metric tonnes (MT) of $\mathrm{CO}_{2}$ equivalent $\left(\mathrm{CO}_{2} \mathrm{e}\right) \mathrm{GHG}$ emissions were produced in 2014 from waste sources including landfills, wastewater treatment, and composting (EPA 2016a). If this waste were used to produce biofuels or bioproducts, the energy use and emissions from the current waste treatment could be avoided. Moreover, byproducts of energy production from waste, including biosolids and biochar, can be applied to soil as soil amendments and fertilizer displacements. Consequently, energy production from waste is receiving an increasing amount of attention.

In the United States, sludge from WWTPs is one of the most abundant waste resources. It is mandatory for municipalities to clean their wastewater before discharging it, and sludge is produced as a byproduct of wastewater treatment. WWTP sludge is a mixture of organic matter that is quite homogeneous and has high energy content. One key challenge of converting sludge into useful types of energy is that doing so usually requires a large amount of energy during the drying process due to its high moisture content, typically $90-94 \%$ after initial dewatering. Thus, energy conversion processes suitable for sludge are very limited. In this study, two processes are selected for generating fuel from sludge: anaerobic digestion (AD) and hydrothermal liquefaction (HTL).

$\mathrm{AD}$ is a biological process that decomposes organic materials into biogas containing 50 $70 \% \mathrm{CH}_{4}$ and $30-50 \% \mathrm{CO}_{2}$. Biogas can be combusted to generate heat and electricity. Once it has been cleaned and upgraded, biogas can also be used to displace natural gas (NG), or it can be further processed to become compressed natural gas (CNG) or liquefied natural gas (LNG). Biosolid, a byproduct digestate produced from the AD process, contains high levels of nutrients - nitrogen $(\mathrm{N})$, phosphorus $(\mathrm{P})$, and potassium $(\mathrm{K})$ - that can be used in soil applications to displace current fertilizers. AD is a mature technology that is widely available in industry. The EPA made several modifications to the renewable fuel standard (RFS2) in 2014; biogas can now be used to get renewable identification number (RIN) credits, which can be a strong motivation for the wastewater industry to produce biogas rather than wasting it. Many WWTPs are interested in producing biofuels, and some are upgrading their AD technologies to increase biogas productivity (e.g., converting to staged or thermophilic AD or implementing pretreatment processes such as thermohydrolysis).

On the other hand, HTL has been developed to convert wet feedstocks, such as algae, into liquid fuels via thermochemical reactions. The HTL process decomposes feedstocks into an organic oil, an aqueous product, non-condensable fuel gases, and a small amount of solids in a pressurized hot water environment. The organic oil is then hydrotreated and hydrocracked into liquid fuels. The aqueous product is processed into fuel gas by catalytic hydrothermal 
gasification $(\mathrm{CHG})$, and fuel gas from previous processes is treated and used to produce hydrogen, power, and steam. A key advantage of HTL for wet waste feedstocks such as sludge from WWTPs is that it does not require an energy-intensive dewatering or dying process. In addition, hydrocarbon fuels from HTL are compatible with the current fuel transportation and distribution infrastructure.

These technologies are used or being developed on the premise that they will generate environmental benefits. However, it is possible that they could consume more energy and generate more emissions than the current treatment practices, because the conversion of sludge to energy could be energy intensive. In order to estimate environmental impacts, a lifecycle analysis (LCA) needs to be applied to account for the energy uses and emissions associated with every stage of the sludge-to-energy pathways. As shown in Figure 1, LCA of ground transportation fuels is also called well-to-wheels analysis because a lifecycle pathway of ground transportation fuels typically includes feedstock recovery (well) and transportation; fuel production, transportation, and distribution; and combustion as an end use (wheels). The stages from exploration and recovery (well) to transportation and distribution (pump) are collectively called well-to-pump (WTP), while the last stage, corresponding to combustion by an internal combustion engine in a vehicle, is called pump-to-wheel (PTW). In the case of waste-based feedstock, the entire pathway is called waste-to-wheels (WTW).

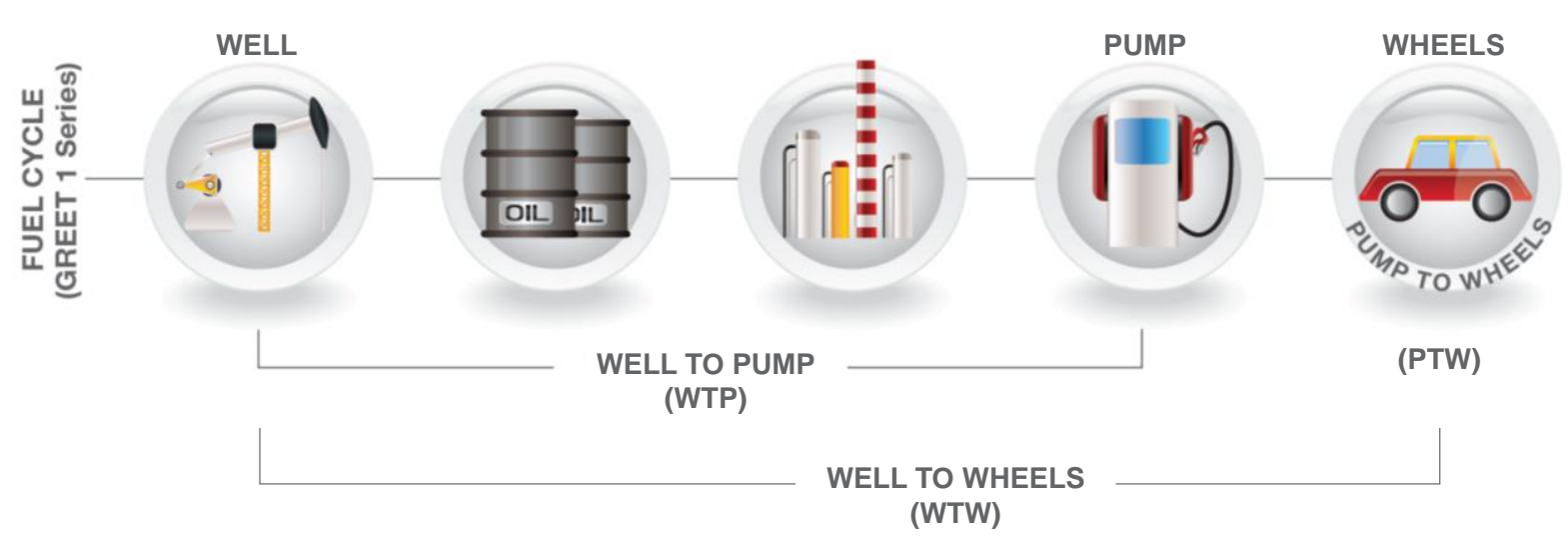

FIGURE 1 Lifecycle Pathway of Ground Transportation Fuels

Recent studies on sludge treatment have shown the economic and environmental advantages of utilizing biogas. Kunetz et al. (2012) evaluated various scenarios for utilizing biogas (e.g., combined heat and power [CHP], plant heating, and sludge drying) produced from Stickney Water Reclamation Plants in Chicago, one of the largest wastewater treatment facilities in the world. They considered three CHP technologies: engines, gas turbines, and steam turbines. The results showed that using biogas in CHP provided the largest economic benefits and GHG emission reductions. Note that GHG emission reductions were calculated by considering the avoided GHG emissions from the displaced electricity and NG by biogas combustion. Ghazy et al. (2011) performed a similar analysis for sludge in Egypt, and concluded that the application of $\mathrm{AD}$ with energy recovery is promising in terms of economic valuation and environmental 
impacts. In particular, they showed that using biogas in larger WWTPs that process more than 2 million gallons per day (MGD) of wastewater can become more cost effective. Yoshida et al. (2013) summarized 35 peer-reviewed journal articles on LCA of sewage sludge management from 1998 to 2012. These articles mostly focused on evaluating WWTPs or sludge management, and some of them studied electricity generation from biogas combustion with existing anaerobic digesters. In the modification to RFS2, the EPA included LCA for CNG and LNG pathways from biogas, which showed a GHG emissions reduction of more than 60\% (40 CFR 80). The system boundary of previous studies, however, is limited to biogas to energy using existing AD, and the environmental impacts of upgrading AD technology for improved performance (e.g., biogas yields, reduced energy consumptions) have not yet been analyzed. Moreover, to the best of our knowledge, no LCA studies have yet been published on direct sludge conversion to hydrocarbon liquid fuels via hydrothermal liquefaction.

In this study, we focused on evaluating energy consumption and GHG emissions for fuel production from sludge through the AD and HTL processes. A key difference between this study and the cited studies is the system boundary. Although the previous studies examine biogas applications, this study includes the sludge conversion processes, namely AD and HTL, thus expanding the system boundary to sludge-to-energy activities. Expanding the system boundary allows us to evaluate the effects of the $\mathrm{AD}$ technologies, $\mathrm{CH}_{4}$ leakages, $\mathrm{CHP}$ options, and digestate types. Through this study, we implemented the WWTP sludge-to-energy pathways into the Greenhouse gases, Regulated Emissions and Energy use in Transportation (GREET ${ }^{\circledR}$ ) model, $^{\circ}$ and evaluated the WTW energy consumptions and GHG emissions. GREET, which was developed by Argonne National Laboratory with the support of the U.S. Department of Energy, is structured to systematically examine the lifecycle energy use and emissions associated with a wide range of vehicle technologies and fuel production pathways from feedstock sources for transportation fuels (Argonne 2015). Energy use in GREET is categorized as fossil (i.e., petroleum, NG, and coal), renewable, and total (the sum of fossil and renewable). GREET includes three conventional GHGs (e.g., $\mathrm{CO}_{2}, \mathrm{CH}_{4}$, and $\mathrm{N}_{2} \mathrm{O}$ ), two optional short-lived GHG emissions (e.g., black carbon and organic carbon), and six criteria pollutant emissions (including $\mathrm{CO}$, volatile organic compounds [VOCs], $\mathrm{SO}_{\mathrm{x}}, \mathrm{NO}_{\mathrm{x}}, \mathrm{PM}_{10}$, and $\mathrm{PM}_{2.5}$ ). 


\section{ANALYSIS APPROACH AND SYSTEM BOUNDARY}

\subsection{ANALYSIS APPROACH}

Figure 2 illustrates the carbon cycle of waste-based feedstock. Current waste management systems treat waste to minimize environmental impacts and meet regulations. In order to treat waste, waste management systems consume energy and generate emissions. Note that some portion of carbon could be stored in soil when landfilled, while the rest is emitted. Currently, sludge from WWTPs is treated using various methods: AD, aerobic digestion, composting, incineration, and landfill. Like other waste-based feedstocks, sludge requires these treatment processes to comply with regulations regardless of the energy and/or nutrient recovery from sludge. Thus, the current waste management system is set as a counterfactual scenario of the alternative energy production pathways. The alternative energy production pathways examine the direct use of waste-based feedstock for the production of fuel that can be used for vehicular applications or power generation; the avoided energy and emissions associated with current waste management systems should be taken into account as credits for WTW analysis. This means marginal changes from the counterfactual scenario are considered in lifecycle energy use and GHG emissions for the waste-to-energy (WTE) pathways. Note that the overlapped upstream stages for both scenarios such as wastewater treatment are consequently excluded.

First, it is important to construct a counterfactual scenario that closely represents the current sludge treatment practice. According to the EPA (2016b), 14,581 WWTPs treat 32,822 MGD of wastewater. Table 1 summarizes the survey data by WWTP size (EPA 2011). The last two rows in Table 1 show the number, average flow rate, and total flow rate of WWTP plants that process volumes of wastewater larger than 1 MGD. WWTPs with less than 1 MGD of wastewater flow might not be suitable for a WTE application due to limited economy of scale.

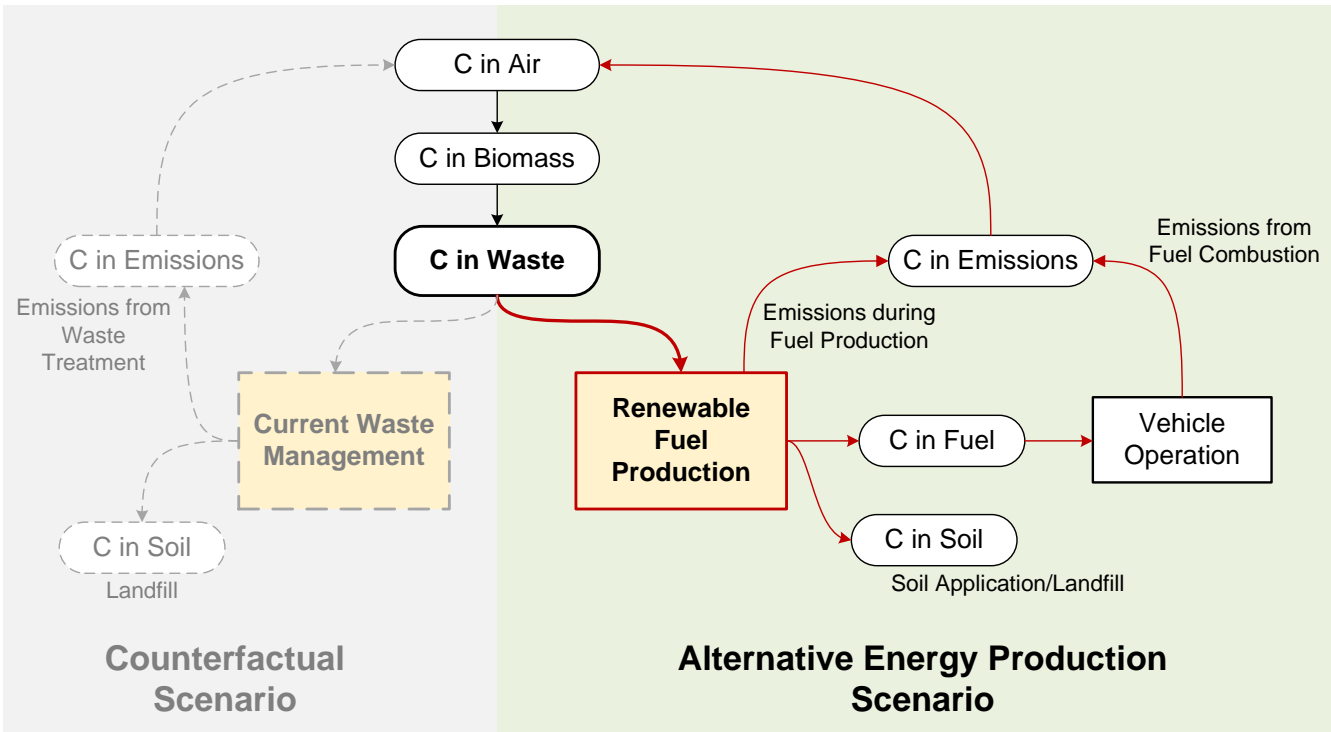

FIGURE 2 Carbon Cycle of Waste-Based Feedstock 
TABLE 1 Number and Wastewater Flow of U.S. WWTP by WWTP Size (EPA 2011)

\begin{tabular}{|c|c|c|c|c|}
\hline \multirow[b]{2}{*}{$\begin{array}{c}\text { WWTP Size } \\
(\mathrm{MGD})\end{array}$} & \multicolumn{2}{|c|}{ Total } & \multicolumn{2}{|c|}{ WWTPs with AD } \\
\hline & $\begin{array}{c}\text { Number of } \\
\text { plants }\end{array}$ & $\begin{array}{c}\text { Average } \\
\text { flowrate } \\
\text { (MGD) }\end{array}$ & $\begin{array}{c}\text { Number of } \\
\text { plants }\end{array}$ & $\begin{array}{c}\text { Average } \\
\text { flowrate } \\
\text { (MGD) }\end{array}$ \\
\hline$<1$ & 13,148 & 0.2 & & \\
\hline $1 \sim 5$ & 2,439 & 2.2 & 2,262 & 2.3 \\
\hline $5 \sim 10$ & 515 & 6.9 & 451 & 7.1 \\
\hline $10 \sim 20$ & 295 & 13.6 & 244 & 14.0 \\
\hline $20 \sim 50$ & 177 & 30.1 & 137 & 30.2 \\
\hline $50 \sim 75$ & 30 & 60.3 & 24 & 61.3 \\
\hline $75 \sim 100$ & 32 & 86.3 & 25 & 86.9 \\
\hline $100 \sim 200$ & 24 & 149.0 & 18 & 150.3 \\
\hline$>200$ & 15 & 347.6 & 10 & 395.0 \\
\hline U.S. Total $(>1)$ & 3,527 & 9.0 & 3,171 & 8.2 \\
\hline Total MGD & & 31,681 & & 26,150 \\
\hline
\end{tabular}

As shown in Table 1, about $90 \%$ of WWTPs that process over 1 MGD employ AD. According to the EPA (2011), however, 66\% of WWTPs with AD do not have CHP, which means that $\mathrm{AD}$ is used for reduction of sludge volume for disposal, but not for energy recovery generally. The WWTPs that use AD but do not recover energy would be advantageous for use in WTE projects, because they require less capital investment. Therefore, the WWTPs with AD but without energy recovery are selected as a counterfactual scenario because they are likely to be replaced with the alternative fuel production pathways.

Anaerobic digesters are mainly classified into two types based on the AD operating temperature. Mesophilic digesters operate at a temperature between $35^{\circ} \mathrm{C}$ and $40^{\circ} \mathrm{C}$, while thermophilic digesters operate between $50^{\circ} \mathrm{C}$ and $55^{\circ} \mathrm{C}$. AD systems can also be designed to have a single stage or multiple stages. Multiple stages are developed to increase biogas yields by separating the processing steps of hydrolysis, acidogenesis, acetogenesis, and methanogenesis. In the United States, the share of thermophilic digesters is only 4\%, although they have higher biogas yields than mesophilic digesters do (WEF 2013). This is mainly because thermophilic digesters require additional energy to maintain higher operating temperatures than mesophilic digesters do, and they are sensitive to temperature control over environmental conditions. Therefore, as assumed in the counterfactual scenario, if biogas is not used for energy recovery but is instead only flared for GHG emissions control, thermophilic digesters could be economically less attractive than mesophilic digesters. Similarly, anaerobic digesters with multiple stages typically utilize produced biogas instead of flaring it, because installing additional stages is costly. Considering that the AD technology for the counterfactual scenario should be chosen from the systems most likely to be replaced with the alternative cases, the 
simplest single-stage mesophilic AD (Meso-1) with flaring biogas can be assumed to be the most appropriate counterfactual scenario.

Digestate is a residue of the AD processes and can be regarded as either a coproduct that may displace fertilizers or waste to be treated, depending on its quality. Based on a survey of digestate applications, 55\% of generated digestate is applied to fields while the remaining $45 \%$ is transported to landfills in the United States (Beecher et al. 2007). Two classes of digestate are generated through AD processes, namely EPA Class A and Class B biosolids (40 CFR 503), which are determined by sludge treatment or AD operating conditions. Class A biosolids contain fewer pathogens because it is generated using high operating temperatures and/or longer retention times, which leads fewer restrictions for soil applications. However, Class B biosolids are treated to minimize pathogen numbers (99\% pathogen reduction) to meet the regulations for disposal. Federal and state regulations for the land application of biosolids are much stricter than those for the use of chemical fertilizers and manure (WERF 2010). Class A biosolids, which are rich in nutrients, displace conventional fertilizers when applied to soil, while Class B biosolids are landfilled. Both classes of biosolids are assumed to sequester some portion of carbon when they are either landfilled or applied to soil. Because the counterfactual case uses a Meso-1 digester without any thermal treatment, it is assumed to generate Class B biosolids (EPA 2006b), which would be landfilled.

Figure 3 shows the counterfactual scenario of the fuel production pathways from sewage sludge. The current sludge treatment includes a Meso-1 anaerobic digester, digestate holding tanks, centrifuge, dewatered digestate storage tanks, biosolid disposal, and biogas flaring and combustion for heat generation. The heat generated in boilers is utilized to meet the onsite thermal demand, and the rest of the biogas is flared to reduce GHG emissions, while required electricity is purchased. Key GHG emissions come from biogas combustion in a boiler, biogas flaring, and upstream activities from the purchased regional electricity. For fossil fuel consumption, only imported electricity is related because biogas is a non-fossil resource.

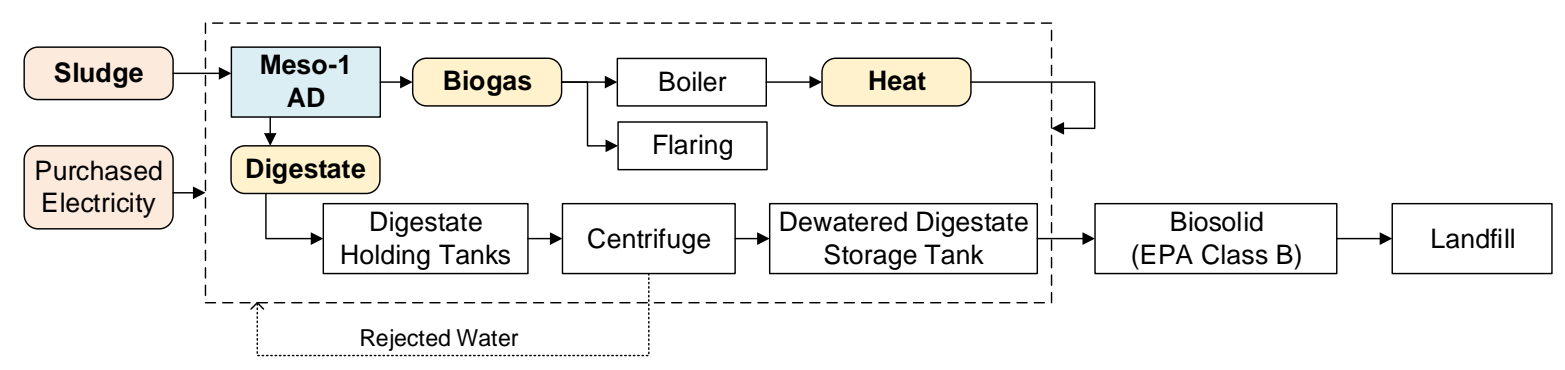

FIGURE 3 Counterfactual Scenario of the Fuel Production from Sewage Sludge

\subsection{ANAEROBIC DIGESTION PATHWAY SYSTEM BOUNDARY}

As shown in Figure 4, the alternative AD case utilizes biogas for energy recovery instead of flaring it as in the counterfactual scenario. It should be noted that other processes (e.g., sludge collection, digestate storage, dewatering, and disposal) are included, similar to the counterfactual 
scenario, which does not lead to significant different impacts between the two systems. The major difference from the counterfactual scenario is that the alternative AD case generates heat and power in CHP by combusting biogas after a first cleanup process. The generated heat from $\mathrm{CHP}$ - along with the heat from the boiler — is used to meet the onsite thermal demand, while the electricity from CHP can be used to meet the onsite electricity demand, and exported if excess exists; in this case, the excess electricity would be credited for replacing regional electricity. The rest of cleaned biogas is processed further (second cleanup) to produce pipeline-quality RNG. RNG is then transmitted to refueling stations via pipeline, compressed, and used in compressed natural gas vehicles (CNGVs); or liquefied onsite, transported to refueling stations via trucks, and used in liquefied natural gas vehicles (LNGVs). Light-duty vehicles (LDVs) and heavy-duty vehicles (HDVs) are set as the baseline pathways for CNG and LNG, respectively, considering their typical applications.

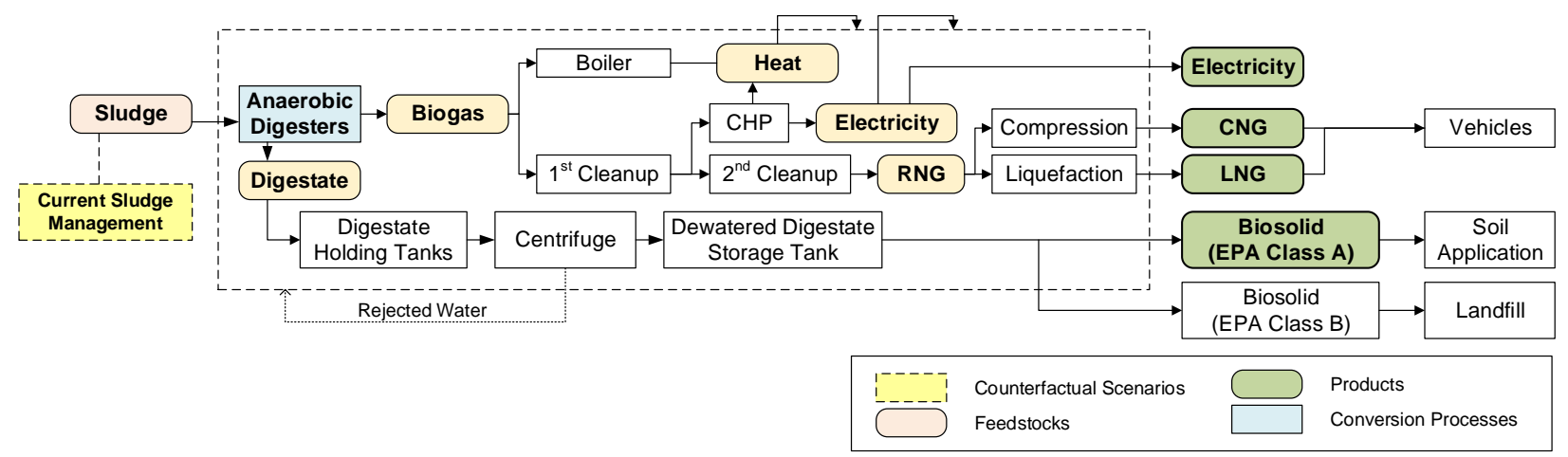

FIGURE 4 WTW Pathway for Wastewater Sludge-based CNG and LNG via AD

In the AD alternative cases, multiple products can be exported, including RNG (either compressed or liquefied), electricity, and digestate. The amount of RNG and exported electricity depend on the amount of cleaned biogas used in CHP. For example, all cleaned biogas can be either combusted in CHP to maximize the electricity export or used for RNG production, using external NG and electricity for the process. This study assumes that a minimum amount of cleaned biogas is used to generate heat and power to maximize RNG production without requiring the use of external $\mathrm{NG}$ and electricity.

Among the energy products (e.g., CNG, LNG, and electricity), either a displacement method or an energy allocation method can be applied. In the displacement method, all energy and emission burdens are assigned to the main product, namely RNG. Assuming the co-products displace conventional products, the energy and emission credits from the displaced conventional product are taken into account. In contrast, the energy allocation method allocates energy and emission burdens to each product by their energy shares. Because co-produced biosolids are not an energy product, a displacement method is applied for biosolids. When Class A biosolids are applied to soil, N, P, and K in biosolids are assumed to displace conventional fertilizers by mass, and a portion of carbon in the biosolid is sequestered. On the other hand, when Class B biosolids 
are disposed of in landfills, only carbon sequestration is taken into account. This study applies the energy allocation method between RNG and excess electricity.

Key parameters for the AD pathways investigated in this study (e.g., AD operation, location, and CHP types) are summarized in Table 2. First, three types of common mesophilic digesters are included-Meso-1, mesophilic 2-stage (Meso-2), and mesophilic-mesophilic acid/gas phase (M-M Phase) digesters (Monteith et al. 2006; Tchobanoglous et al. 2013) because mesophilic digesters are the majority, while thermophilic digesters account for only a small portion (4\%) in the United States (WEF 2013). The effect of applying thermohydrolysis (TH) prior to Meso-1 is also investigated. Unlike Meso-1, Meso-2 has a secondary tank that only works as a storage tank to provide thickening, with neither heating nor mixing. On the other hand, M-M Phase separates tanks based on their acidity to maximize biogas yields by building preferable conditions for each AD stage. Two different models (semi-empirical and Aspen) are used to simulate the AD processes, and an additional eight AD technologies are also implemented in the GREET model beyond the AD types in Table 2. The semi-empirical model includes Meso-1, mesophilic-thermophilic acid/gas phase (M-T Phase), thermophilic 1 stage (Thermo-1), thermophilic 2 stage (Thermo-2), mesophilic-thermophilic temperature-phased (MT TPAD) and thermophilic-mesophilic temperature-phased (T-M TPAD). For the Aspen model, cases of Meso-1 and Meso-1 TH with conservative yield assumptions are considered as well. The parametric assumptions for the additional $\mathrm{AD}$ technologies are presented in the Appendix A.

Other than the AD technologies, four types of CHP are investigated: micro-turbines and internal combustion engines that represent common combustion technologies and two possible future options (molten carbonate fuel cell $[\mathrm{MCFC}]$ and phosphoric acid fuel cell [PAFC]). The location of WWTPs affects the thermal energy requirement of the AD due to the different climate conditions prevalent at each location. To represent cool, temperate, and warm climates, respectively, in the United States, Illinois (IL), California (CA), and Florida (FL) are selected for their WWTP locations. Note that location does not indicate the regional difference in energy and carbon intensities of baseline fuels (electricity, NG, etc.). A recent EPA study shows that California and Florida have the greatest CHP capacities (EPA 2011). However, according to this study, Illinois has two sites with CHP systems; the largest of the Chicago treatment facilities, where CHP is economically attractive, make Illinois an important candidate for this analysis. The annual average temperatures of Illinois, California, and Florida are reported to be 11, 15.3, and $21.5^{\circ} \mathrm{C}$, respectively (NCDC 2012).

TABLE 2 WWTP Cases Selected for Analysis

\begin{tabular}{|c|c|}
\hline Parameters & Alternative AD Cases (Models) \\
\hline AD technology & $\begin{array}{l}\text { Meso-1 (Aspen) } \\
\text { Meso-1 with TH (Aspen) } \\
\text { Meso-2 (semi-empirical) } \\
\text { M-M Phase (semi-empirical) }\end{array}$ \\
\hline CHP types & micro-turbine, engine, $\mathrm{MCFC}, \mathrm{PAFC}$ \\
\hline Location & $\mathrm{IL}, \mathrm{CA}, \mathrm{FL}$ \\
\hline
\end{tabular}




\subsection{HYDROTHERMAL LIQUEFACTION PATHWAYS SYSTEM BOUNDARY}

As shown in Figure 5, a HTL case requires hydrogen and electricity inputs along with sewage sludge, and produces renewable diesel fuels with its co-products, light gases and fuel oil. The residues of the process consist of ash and char; these residues are regarded as sequestering $80 \%$ of carbon they contain. A portion of the light gases generated during the process are combusted to support the heat and electricity demands of the process, and extra light gas is regarded as a co-product. The energy allocation method is used in order to handle the coproducts. This method allocates the energy and emission burdens of the hydrocarbon fuel based on the hydrocarbon fuel's energy share in the total energy production. The Meso-1 AD without energy recovery case explained above is also used as a counterfactual scenario because it represents the conventional sludge treatments. The HTL conversion pathways of wastewater sludge are simulated using an Aspen model.

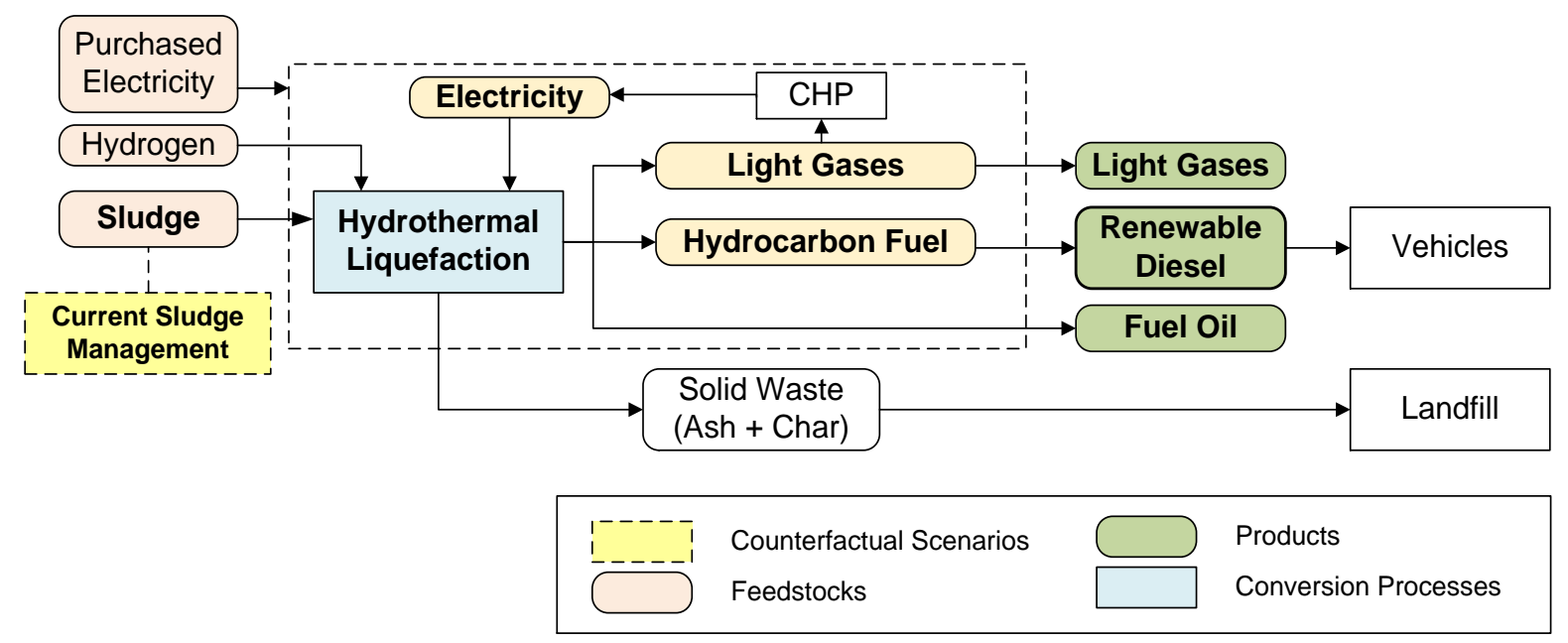

FIGURE 5 WTW Pathway for Wastewater Sludge-based Renewable Diesel via HTL 


\section{PARAMETRIC ASSUMPTIONS OF WASTE-TO-ENERGY PATHWAYS}

Comprehensive evaluation of the benefits by these WTE pathways relative to those of fossil-based fuel production pathways requires an LCA where the energy and emissions from all stages in the lifecycle of the fuels are taken into account. For this LCA, simulations are performed using Aspen models for AD and HTL, and an additional empirical model is used for a separate $\mathrm{AD}$ simulation. The details are described in the following sections.

\subsection{SEWAGE SLUDGE CHARACTERIZATION}

Sewage sludge characteristics vary by many factors (e.g., region, wastewater characteristics, treatment processes). Therefore, this study reviewed various research articles to develop the characteristics of sludge as presented in Table 3 (Del Borghi et al. 1999; Environmental Research Information Center 1978; Gray et al. 2008; Harrison et al. 1974; Heidrich et al. 2010; Inoue et al. 1996; Kim et al. 2004; Lemoine et al. 2013; Parnaudeau et al. 2004; Sosnowski et al. 2003; Tchobanoglous et al. 1993; EPA 1999; Xu et al. 2013; Zhao et al. 2011). Sewage sludge typically contains approximately 6,500 to $12,500 \mathrm{Btu} / \mathrm{lb}$. on a dry weight basis, which is similar to the energy content of low-grade coal (Moss et al. 2013).

TABLE 3 Characteristics and Composition of Sewage Sludge Feedstock

\begin{tabular}{lc}
\hline Basic Characteristics & $\begin{array}{c}\text { Aspen Model } \\
\text { (wt. } \% \text { ) }\end{array}$ \\
\hline Total dry solids (TS) & $8.0 \%$ \\
Volatile solids (\% of TS) & $61.0 \%$ \\
Energy content (Btu/dry lb.) & 6851 \\
& \\
Component Composition & \\
Grease and fats (\% of TS) & $17.7 \%$ \\
Protein (\% of TS) & $29.2 \%$ \\
Carbohydrate (\% of TS) & $11.4 \%$ \\
Ash (\% of TS) & $39.0 \%$ \\
& \\
Elemental Composition & \\
Carbon (\% of TS) & $35.6 \%$ \\
Hydrogen (\% of TS) & $5.0 \%$ \\
Oxygen (\% of TS) & $14.8 \%$ \\
Sulfur (\% of TS) & $0.4 \%$ \\
Nitrogen (\% of TS) & $5.2 \%$ \\
Ash (\% of TS) & $39.0 \%$ \\
\hline
\end{tabular}




\subsection{WASTEWATER COLLECTION AND WWTP}

Once wastewater is generated, it is collected and transported to wastewater treatment facilities, typically in non-pressurized conduits (sewers) by gravity. Depending on local topography, however, some wastewater is pumped and transported via pressurized pipelines. Electricity consumption for pumping depends largely on system hydraulics (e.g., flow rate, viscosity, and topography), which vary by region, climate, and local population. In this study, the energy requirements for the wastewater collection and treatment processes are excluded because they are part of the wastewater treatment system, which are out of the WTE system boundary. However, the collected energy requirement data are documented for future use in Appendix B.

\subsection{ANAEROBIC DIGESTER}

Argonne National Laboratory (Argonne) and the National Renewable Energy Laboratory (NREL) performed two independent simulations using a semi-empirical model and an Aspen model, respectively. Details are explained in the following sections.

\subsubsection{Semi-Empirical Model}

A semi-empirical model is used to simulate the Meso-2 and M-M Phase digesters. Key parameters of $\mathrm{AD}$ are biogas yields, heat and electricity requirements, and $\mathrm{CH}_{4}$ emissions. First, biogas yields can be estimated using volatile solids reduction (VSR) because biogas is generated while a part of volatile solids (VS) is destructed. Argonne performed simulations for sludge AD using empirical data collected by Water Environment Research Foundation (WERF) (Monteith et al. 2006). WERF developed a semi-empirical model, the Life Cycle Assessment Manager for Energy Recovery (LCAMER) spreadsheet, which estimates VSR based on its previous research and survey (Kalogo et al. 2005). In order to calculate VSR, concentrations of VS entering and leaving the digesters need to be calculated. These values are affected by several parameters, such as sludge retention time (SRT) and digester operating temperature.

The SRTs for the Meso-2 are set as 10 days for the first stage and 5 days for the second stage. Similarly, for the M-M Phase, 2 days and 13 days, respectively, are used. VSRs are estimated as 56\% and 50\% for the Meso-2 and M-M Phase, respectively, using the SRT and the operating temperature for each AD technology. Once VSR is calculated, biogas production rate, $\mathrm{CH}_{4}$ production rate, generated digestate, and required polymer for dewatering can be calculated. The biogas production rates are set to $0.9 \mathrm{~m}^{3} / \mathrm{kg}$ VS destroyed with $65 \%$ of $\mathrm{CH}_{4}$ (Monteith et al. 2006). Therefore, the multiplication of the biogas production rate and the VSR represents biogas yield for VS loading.

Thermal energy requirements for the processes can be divided into two major parts: one for increasing the sludge temperature to the operating temperature of $\mathrm{AD}$ and the other representing heat loss from $\mathrm{AD}$ to the atmosphere. The former is a function of sludge properties and temperature, $\mathrm{AD}$ operating temperature, and sludge loading rate, while the latter depends on 
the size (i.e., surface area) of the digester and heat-transfer-related parameters, as well as the difference between the digester and the ambient temperature.

The energy needed to heat sludge is calculated by multiplying the sludge loading rate with the average sludge density, the average specific heat of sludge, and the difference between the digester operating temperature and the sludge temperature, divided by the heat exchanger efficiency. The average density and the average specific heat of sludge are assumed to be $1,020 \mathrm{~kg} / \mathrm{m}^{3}$ and $4,200 \mathrm{~J} / \mathrm{kg} \cdot{ }^{\circ} \mathrm{C}$, respectively (Monteith et al. 2006). Climate is an important factor in determining digester heating requirements, because more energy is required to heat the digesters when ambient air and sludge temperatures are low. The average sludge temperature is assumed to be the same as the annual average ambient temperature at each location. The operating temperatures for mesophilic digesters are set to $35^{\circ} \mathrm{C}$, and heat exchanger efficiency is set to $80 \%$.

The additional thermal energy for making up heat loss can be calculated by multiplying a heat transfer coefficient, AD surface area, and the temperature difference between the digester and the ambient temperature, and then dividing by the heat exchanger efficiency. The heat transfer coefficient is assumed to be $0.8 \mathrm{~W} / \mathrm{m}^{2} \mathrm{~K}$, and $80 \%$ is used for the heat exchange efficiency. The surface area is calculated using the size of the AD reactors, which depends on the WWTP sizes. Smaller AD facilities require more thermal energy per given VS loading. Total thermal energy requirements per kilogram VS loaded are tabulated in Table 4 for three different locations with three different WWTP sizes. Because the studied mesophilic anaerobic digesters all operate at $35^{\circ} \mathrm{C}$, there is no difference due to the types of anaerobic digesters.

TABLE 4 Thermal Energy Requirement of Mesophilic Digesters (MJ/kg VS loaded)

\begin{tabular}{lccc}
\hline & \multicolumn{3}{c}{ Locations } \\
\cline { 2 - 4 } Size of WWTP & IL & CA & FL \\
\hline & & & \\
5 MGD & 4.56 & 3.88 & 2.89 \\
20 MGD & 4.28 & 3.65 & 2.73 \\
100 MGD & 4.08 & 3.48 & 2.62 \\
\hline
\end{tabular}

Based on the LCAMER results, we developed a response surface model to estimate the total thermal energy requirements for other conditions. The total can be expressed as the sum of baseline and marginal energy requirements. The marginal fraction depends on the AD conditions, while the baseline portion is a constant that satisfies minimum demands as defined in Eq. (1),

$$
\begin{aligned}
E_{\text {Thermal }} & =E_{\text {Base }}+E_{\text {Marginal }}=E_{\text {Base }}+c_{A D} \cdot \Delta T \\
& =E_{\text {Base }}+\left(\alpha+\beta \times[\text { sludge intake }]^{-0.34}\right) \times\left(T_{\text {operating }}-T_{\text {amb }}\right)
\end{aligned}
$$

Where $E_{\text {Thermal }}, E_{\mathrm{Base}}$, and $E_{\text {Marginal }}$ are total, base, and marginal thermal energy requirements, respectively. The variable $c_{\mathrm{AD}}$ represents the $\mathrm{AD}$ specific thermal energy requirement in terms of $\mathrm{MJ} / \mathrm{kg} \cdot{ }^{\circ} \mathrm{C}$, which is determined empirically for each AD operating condition. It is a function of the amount of sludge intake in $\mathrm{m}^{3} /$ day where $\alpha$ and $\beta$ are constants. For the mesophilic digesters, $\alpha$ and $\beta$ are calculated to be 0.1275 and 0.2084 , respectively, using the LCAMER data. $\Delta T$ 
represents the difference between the operating temperature, $T_{\text {operating, }}$, and the ambient temperature, $T_{\mathrm{amb}}$.

Electricity consumption is assumed to be proportional to total digester volume at $6.5 \mathrm{~W}$ per cubic meter of digester (Monteith et al. 2006). The working digester volume is calculated by multiplying SRT with the sludge loading rate, and it is assumed that the working digester volume is $90 \%$ of the total digester volume. Resulting electricity consumption for mesophilic digesters is $0.367 \mathrm{MJ} / \mathrm{kg}$ VS loaded $(65 \mathrm{kWh} / \mathrm{MT})$, which is within the range reported in literature of 9-70 kWh/MT (Møller et al. 2009; Pertl et al. 2010; Sanscartier et al. 2012; Zwart et al. 2011).

During AD processes, $\mathrm{CH}_{4}$ emission occurs, and this has significant effects on the total GHG emissions. $\mathrm{CH}_{4}$ emission for each stage is explained and summarized in Section 3.3.3, because there are additional $\mathrm{CH}_{4}$ emissions from the generated digestate during the holding and storage processes and from the disposed digestate.

Digestate consists of inert solids in sludge and non-destructed digestible solids in VS that remains after $\mathrm{CH}_{4}$ generation. The difference between TS and VS is caused by the amount of inert solid; the digestible solid in digestate can be estimated by subtracting the amount of inert solid from the solid in the digestate. It is assumed that the M-M Phase generates Class A biosolids, because the process is known to reduce pathogens (EPA 2006a), while Meso-2 produces Class B biosolids.

\subsubsection{Aspen Model}

NREL conducted a techno-economic analysis for sludge AD using an Aspen model for Meso-1 and Meso-1 with TH; the schematic of this model is shown in Figure 6. In this simulation model, the sludge feedstock is regarded as a combination of protein, lipid, cellulose, lignin, and hemicellulose. The mesophilic digestion process is where long-chain organic compounds (e.g., proteins, fats, and carbohydrates) are decomposed to simple amino acids, fatty acids, and sugars. This is followed by hydrolysis/liquefaction, acidogenesis, and methanogenesis. The biogas production rate is assumed to be $0.19 \mathrm{~kg} \mathrm{CH} / \mathrm{kg} \mathrm{VS}$, and the hydraulic retention time (HRT) is set at 25 days. In order to study the effect of adding pretreatments, an alternative case with dewatering and thermohydrolysis processes prior to the AD was also investigated. First, wet sludge feedstock that consists of $90-96 \%$ moisture is processed to reach $20 \%$ total solids through a dewatering process. The slurry is then processed in a thermohydrolysis reactor by heating it up to $165^{\circ} \mathrm{C}$ under 6 bar of pressure for 20 minutes. The thermohydrolysis process is known to enhance biogas yields by increasing the efficiency of the biological processes (Ruggeri et al. 2012; Vavouraki et al. 2013; Wagland et al. 2011). Applying the thermohydrolysis process is also expected to generate Class A biosolids. After cooling the sludge and lowering its pressure, it is moved to a mesophilic digester. For the $\mathrm{AD}$ with thermohydrolysis, the biogas production rate is set at $0.27 \mathrm{CH}_{4} \mathrm{~kg} / \mathrm{kg} \mathrm{VS}$, which is higher than that of the conventional ADs, and a shorter HRT of 21 days is used. 


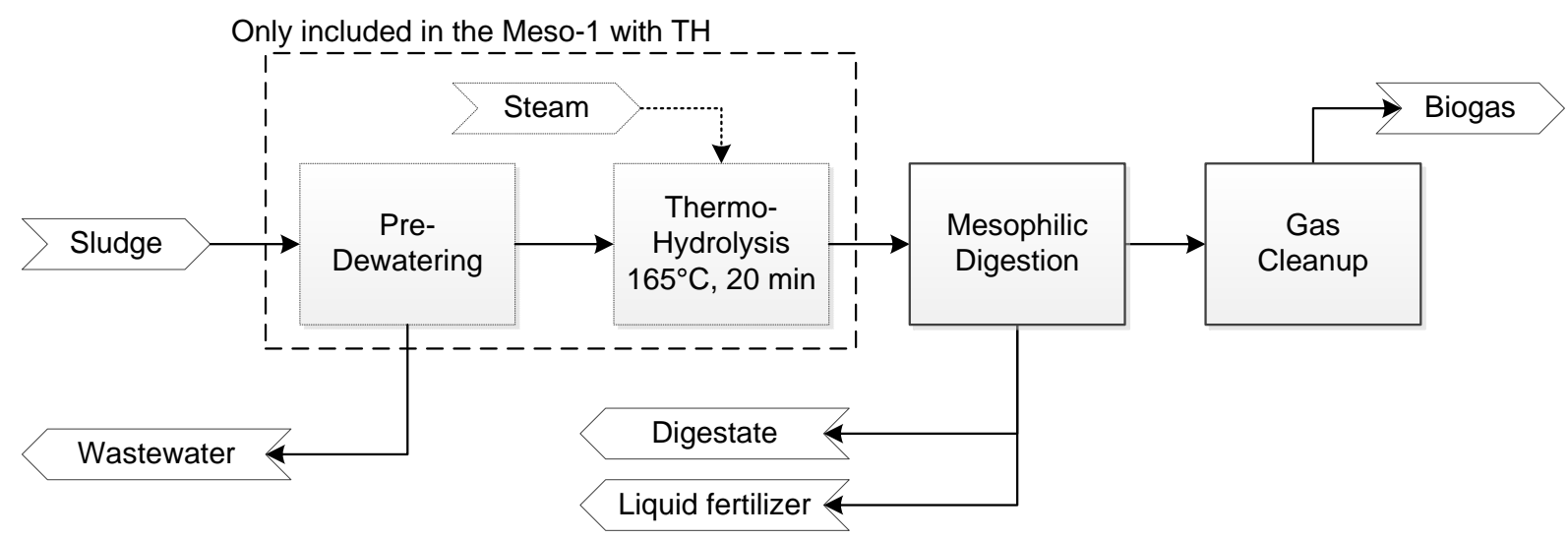

FIGURE 6 Process Diagram of the Aspen AD Model Using Sludge

Thermal and electric energy requirements are estimated from the Aspen model. Total electrical energy requirements are 0.55 and $1.3 \mathrm{MJ} / \mathrm{kg} \mathrm{VS}$, for the Meso-1 and the Meso-1 with $\mathrm{TH}$, respectively. Thermal energy consumption is evaluated by adding up the estimated requirements for each process and the heat loss from the facility; this yields $0.83 \mathrm{MJ} / \mathrm{kg} \mathrm{VS}$ for the Meso-1 and 5.15 MJ/kg VS for the Meso-1 with TH. However, the estimated thermal energy requirement for the Meso-1 case is too small to heat up the input sludge and to maintain the mesophilic AD operation temperature. Therefore, the semi-empirical method is used instead to estimate thermal energy requirement for Meso- 1 , which is $4.1 \mathrm{MJ} / \mathrm{kg} \mathrm{VS}$. Table 5 summarizes major parameters calculated for the AD simulations. The VSR values of the Aspen model are calculated using the $\mathrm{CH}_{4}$ yield results from the simulation for comparison with the semiempirical model.

TABLE 5 Key Parameters for the AD Simulations

\begin{tabular}{|c|c|c|c|c|}
\hline \multirow[b]{2}{*}{ Parameter } & \multicolumn{2}{|c|}{ Aspen Model } & \multicolumn{2}{|c|}{$\begin{array}{c}\text { Semi-Empirical } \\
\text { Model }\end{array}$} \\
\hline & Meso-1 & $\begin{array}{c}\text { Meso-1 } \\
\text { with TH }\end{array}$ & Meso-2 & $\begin{array}{l}\text { M-M } \\
\text { Phase }\end{array}$ \\
\hline Volatile solid reduction (VSR, \%) & $45 \%$ & $64 \%$ & $56 \%$ & $50 \%$ \\
\hline $\begin{array}{l}\text { Total electrical energy requirement }(\mathrm{MJ} / \mathrm{kg} \\
\text { VS) }\end{array}$ & 0.55 & 1.3 & 0.37 & 0.37 \\
\hline Total thermal energy requirement $(\mathrm{MJ} / \mathrm{kg} \mathrm{VS})$ & 4.1 & 5.1 & 4.1 & 4.1 \\
\hline AD operating temperature $\left({ }^{\circ} \mathrm{C}\right)$ & 35 & $35^{\mathrm{a}}$ & 35 & 35 \\
\hline Supernatant flow rate $\left(\mathrm{m}^{3} / \mathrm{kg} \mathrm{VS}\right)$ & 0.019 & 0.010 & 0.036 & 0.036 \\
\hline Digestate class by EPA & Class B & Class A & Class B & Class A \\
\hline Solid in digestate (kg/kg VS loaded) & 1.19 & 1.00 & 1.08 & 1.14 \\
\hline
\end{tabular}

a $\mathrm{TH}$ is operated at $165^{\circ} \mathrm{C}$. 


\subsubsection{Digestate and Supernatant}

Characteristics of the digestate generated from each AD technology, such as the fractions of digestible solid in digestate, are assumed to be the same and independent of the applied AD type. In reality, however, digestion technology can affect the digestate characteristics and the selection and operation of downstream processes (Moss et al. 2011). Digestate from AD is stored in holding tanks and dewatered, then the dewatered digestate (or biosolids) is stored in storage tanks before it is disposed of in a landfill or applied to soil as a soil amendment. Key parameters in digestate treatment include electricity and polymer consumptions in dewatering; the quality of biosolids, which determines its subsequent application (e.g., landfill or soil application); carbon sequestration by biosolids; fertilizer displacements by biosolid application; and $\mathrm{CH}_{4}$ emissions.

Electricity requirements in this stage can be estimated by considering key digestate treatment processes. Centrifuging is the most common dewatering process (Tchobanoglous et al. 2013), and typical centrifuges use $101.4 \mathrm{kWh}$ electricity per MT dry solids treated (Brown et al. 2010). For the polymers, there is a large variability in chemical composition, and in functional and cost effectiveness (Wang et al. 2007). Because Acrylonitrile-type polymers have been extensively used in digestate conditioning, Acrylonitrile-Butadiene-Styrene (ABS) is employed with a default dosage of $5 \mathrm{~kg}$ polymer per MT dry solids (Brown et al. 2012). The total volume of generated biosolid ( $\mathrm{m}^{3} / \mathrm{kg}$ VS) is then calculated assuming a solid content of $30 \%$ after centrifugation with polymer aid (Tchobanoglous et al. 2013); this is equivalent to $3 \mathrm{~m}^{3}$ sludge per ton of dry solid disposed.

As mentioned, EPA Class A biosolids can displace current fertilizer, while Class B cannot. In this study, Meso-1 and Meso-2 are assumed to generate Class B biosolids, while Meso-1 with TH and the M-M Phase produce Class A (EPA 2006b). In the case of EPA Class A biosolids, the credits obtained by reducing the need for mineral fertilizer production are included in this analysis. In Class A biosolids, $\mathrm{N}$ content has been simulated to be $4.1 \%$ of solid in digestate, while $\mathrm{P}$ and $\mathrm{K}$ are estimated to be $2.3 \%$ and $0.3 \%$, respectively, of solids in digestate (Tchobanoglous et al. 2013). It is assumed that $\mathrm{N}, \mathrm{P}$, and $\mathrm{K}$ in Class A biosolids displace $\mathrm{N}$, $\mathrm{P}_{2} \mathrm{O}_{5}$, and $\mathrm{K}_{2} \mathrm{O}$ fertilizers by mass, respectively, and carbon is sequestered. Transportation to fields or landfills is assumed to be 40 miles via trucks.

$\mathrm{AD}$ also generates supernatant, which is liquid effluent. For the semi-empirical model, the amount of supernatant is estimated by subtracting total dry biosolids to be disposed from input sludge, producing a result of $0.036 \mathrm{~m}^{3} / \mathrm{kg}$ VS. For the Aspen model, supernatant flow rates are calculated to be 0.019 and $0.010 \mathrm{~m}^{3} / \mathrm{kg}$ VS for the Meso- 1 and Meso- 1 with TH, respectively.

$\mathrm{CH}_{4}$ emissions from each stage-including the AD process, digestate, and soil and land applications - are calculated using measured $\mathrm{CH}_{4}$ emission data from the literature, and summarized in Table $6 . \mathrm{CH}_{4}$ leakage is proportional to total biogas production during the $\mathrm{AD}$ process; this leakage is estimated to be $1 \%$ by volume (Han et al. 2011). The amount of emissions from digestate is closely related to holding and storage duration, as well as the amount of digestate. Daelman et al. (2012) measured $\mathrm{CH}_{4}$ emissions from every stage of municipal wastewater treatment, including $\mathrm{AD}$ processes. Emissions measured from holding and storage stages are 3.5 and $1 \mathrm{~g} \mathrm{CH}_{4}$, respectively, per kilogram of total suspended solids (TSS) per day. 
These are equivalent to 0.005 and $0.001 \mathrm{~m}^{3} \mathrm{CH}_{4} / \mathrm{kg}$ digestible solid in digestate per day, respectively. Considering the ratio between the emissions measured from the holding tank and those from the centrifuge is 4 to 1 , and the holding duration is 5 days, $\mathrm{CH}_{4}$ emissions from the centrifuge can be estimated at $0.004 \mathrm{~m}^{3} \mathrm{CH}_{4} / \mathrm{kg}$ digestible solid in digestate. In this study, according to the survey by Daelman et al. (2012), holding and storage durations are assumed to be 5 days and 10 days, respectively, during typical operations. Due to their different properties and atmosphere, biosolids disposed of in landfills and applied to soil have different $\mathrm{CH}_{4}$ emissions. Dieterich et al. (2012) and Mosher et al. (1999) measured $\mathrm{CH}_{4}$ from biosolids applied to soil and disposed of in landfills, respectively; this is equivalent to 0.013 and $0.001 \mathrm{~m}^{3} \mathrm{CH}_{4} / \mathrm{m}^{3}$ digestate disposed. Using measured data, $\mathrm{CH}_{4}$ emission from supernatants is also estimated to be $10 \mathrm{mg} / \mathrm{L}$, which is equivalent to $0.014 \mathrm{~m}^{3} \mathrm{CH}_{4} / \mathrm{m}^{3}$ supernatant (De Haas et al. 2009; Foley and Lant 2009).

\section{TABLE 6 Methane Emission Rates}

\begin{tabular}{|c|c|}
\hline From & $\mathrm{CH}_{4}$ Emissions \\
\hline Digester (leaks and maintenance) ${ }^{\mathrm{a}}$ & $0.010 \mathrm{~m}^{3} \mathrm{CH}_{4} / \mathrm{m}^{3}$ total biogas production \\
\hline Digestate holding tank $\mathrm{k}^{\mathrm{b}}$ & $0.005 \mathrm{~m}^{3} \mathrm{CH}_{4} / \mathrm{kg}$ digestible solid in digestate/day \\
\hline Digestate centrifuges ${ }^{\mathrm{b}}$ & $0.004 \mathrm{~m}^{3} \mathrm{CH}_{4} / \mathrm{kg}$ digestible solid in digestate \\
\hline Digestate storage $\operatorname{tank}^{\mathrm{b}}$ & $0.001 \mathrm{~m}^{3} \mathrm{CH}_{4} / \mathrm{kg}$ digestible solid in digestate/day \\
\hline Digestate applied to soil ${ }^{\mathrm{c}}$ & $0.013 \mathrm{~m}^{3} \mathrm{CH}_{4} / \mathrm{m}^{3}$ digestate disposed \\
\hline Landfilled digestate $^{\mathrm{d}}$ & $0.001 \mathrm{~m}^{3} \mathrm{CH}_{4} / \mathrm{m}^{3}$ digestate disposed \\
\hline Supernatant $\mathrm{e}^{\mathrm{e}}$ & $0.014 \mathrm{~m}^{3} \mathrm{CH}_{4} / \mathrm{m}^{3}$ supernatant \\
\hline \multicolumn{2}{|l|}{ a Han et al. (2011). } \\
\hline \multicolumn{2}{|l|}{ b Daelman et al. (2012). } \\
\hline \multicolumn{2}{|l|}{ c Dieterich et al. (2012). } \\
\hline d Mosher et al. (1999). & \\
\hline
\end{tabular}

Non-combustion $\mathrm{CO}_{2}$ emissions can be estimated from the amount of sequestered carbon in digestate because the rest of sequestered carbon is regarded to be emitted in the form of $\mathrm{CH}_{4}$ and $\mathrm{CO}_{2}$. It is assumed that $20 \%$ of carbon in digestate by weight is sequestered.

\subsubsection{Biogas Combustion and Flaring}

As shown in Figure 3, required heat for the counterfactual scenario is provided from biogas combustion in a boiler, and the rest of the biogas is assumed to be flared to reduce GHG emissions. For the AD alternative cases, a CHP system is included as in Figure 4 to support electric energy as well as heat, and the rest of the biogas is assumed to be sent to further upgrading processes for CNG and LNG production. The energy conversion efficiency and thermal energy recovery factor for each CHP technology are shown in Table 7. It is assumed that 
the boilers burn raw biogas without any cleaning process with an efficiency of $80 \%$, while CHPs require biogas that has been treated through the first cleanup process. The electric energy needed for the first cleanup process can be supported by the CHP when enough biogas is produced, while external electricity is used when there is not.

TABLE 7 CHP Electrical Efficiency and Thermal Energy Recovery Factor by Prime Movers

\begin{tabular}{lcccc}
\hline \multicolumn{1}{c}{ Efficiency } & $\begin{array}{c}\text { Micro- } \\
\text { Turbine }\end{array}$ & Engine & MCFC & PAFC \\
\hline & & & & \\
CHP generator electrical efficiency & $34 \%$ & $30 \%$ & $48 \%$ & $35 \%$ \\
Heat recovery efficiency from CHP generator & $70 \%$ & $70 \%$ & $50 \%$ & $50 \%$ \\
\hline
\end{tabular}

\subsubsection{Biogas Cleanup and Upgrading to CNG/LNG}

Once raw biogas is cleaned up in the first cleanup process, it is sent to CHP to generate heat and power to sustain the AD facility, and the rest heads to additional upgrading processes. The NG processing efficiency is estimated to be $94.4 \%$ (Mintz et al. 2010), assuming a two-stage cleanup process. During the biogas upgrading process, $2 \%$ of produced $\mathrm{CH}_{4}$ by volume is estimated to be leaked (Börjesson and Berglund 2006). Assuming each stage of the cleanup process has the same energy intensity and $\mathrm{CH}_{4}$ leakage rate, the total electricity consumption and $\mathrm{CH}_{4}$ leakage rate are divided into each stage, which results in 0.03 MJe of electricity consumption per $\mathrm{MJ}$ feed and a $1 \% \mathrm{CH}_{4}$ leakage rate for each cleanup process.

RNG can be further compressed for CNG LDVs or liquefied for LNG HDVs. All assumptions are taken from the previous RNG pathways in GREET (Han et al. 2011). RNG can be compressed to 4,000 psia by electric compressors at either onsite or offsite refueling stations. For the offsite refueling case, RNG is assumed to be transported 50 miles through pipelines. Alternatively, RNG can be liquefied by onsite liquefiers with $89 \%$ liquefying efficiency when it uses single mixed refrigerant and expander processes. Once it is liquefied, it then is assumed to be transported by trucks to offsite stations located 50 miles away.

\subsection{HTL PROCESSES}

The sludge HTL Aspen model shown in Figure 7 consisted of eight subsystems: HTL, hydrotreating, hydrocracking, catalytic hydrothermal gasification (CHG), gas conditioning, hydrogen plant, CHP, and utilities. HTL is set in subcritical water at an elevated temperature $\left(300-360^{\circ} \mathrm{C}\right)$ and pressure (150-200 bar). The reactor produces effluents of the organic oil phase and aqueous phase, non-condensable gases, and a small amount of solids. The simulation based on research results from the literature (Wang 2011; Yong and Matsumura 2012, 2013). 


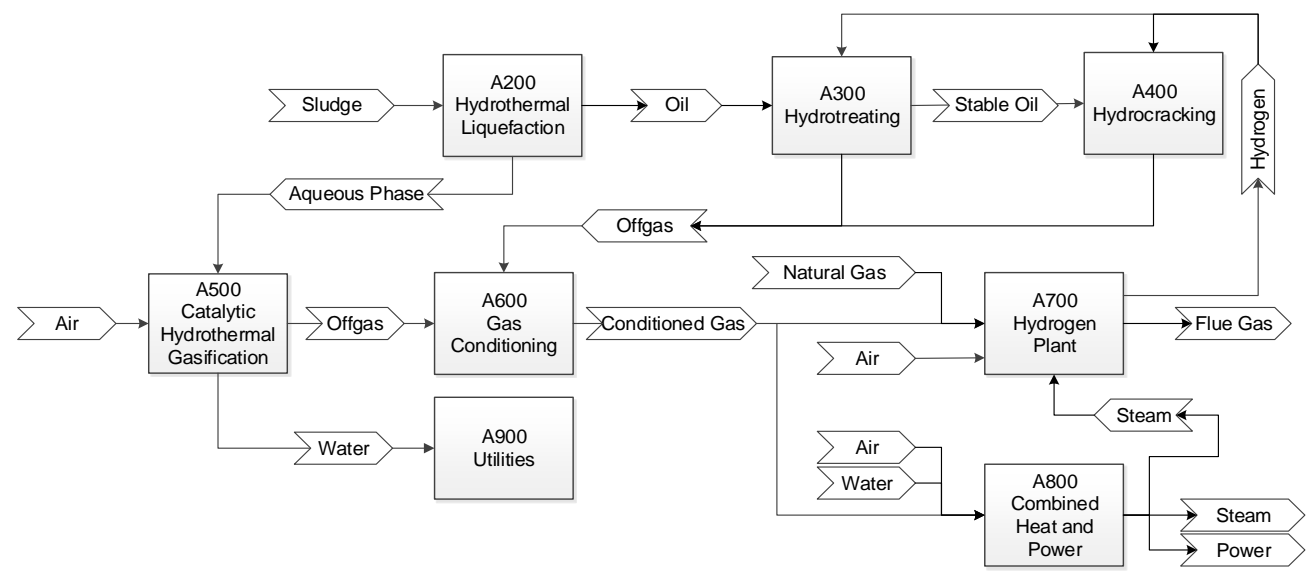

FIGURE 7 Process Diagram of the Aspen HTL Model using Sewage Sludge

Hydrotreating is a process to reduce the oxygen content of the oil from HTL process. $\mathrm{H}_{2}$ is provided and mixed with the oil, and then preheated. The main process occurs at around $403^{\circ} \mathrm{C}$ and 10.6 MPa, and then the effluent is cooled and separated into water, offgas, and hydrotreated oil phase. The oil compounds and yields are estimated based on the joint design report from NREL and Pacific Northwest National Laboratory (PNNL) (Jones et al. 2013). The hydrotreated oil is then moved to a hydrocracking area where renewable gasoline and diesel fuels are produced. Hydrocracking is a process used to separate the heavy portion of stable hydrocarbon oil into gasoline and diesel range fuels. In this simulation, a commercial hydrocracking reactor, the Two-Stage Unicracking ${ }^{\mathrm{TM}}$ Process from Honeywell UOP, is selected for the hydrocracking process. It mixes stable hydrocarbon oil with $\mathrm{H}_{2}$ at around $370^{\circ} \mathrm{C}$ and 7.1 MPa. It produces a mixture of gasoline and diesel range liquid fuels with byproduct gases. $\mathrm{H}_{2}$ can be recovered from the offgas generated from the hydrotreating and hydrocracking processes through pressure swing adsorption (PSA), and this can subsequently be used again to support the processes.

CHG can convert organic materials into gas that can be utilized. In this simulation, it is used for the aqueous phase from HTL to recover the carbon contained in water. First, salt brine is removed from the water stream because the brine negatively impacts hydrothermal gasification (Toonssen et al. 2010). The separated organics are then fed to the gasifier at around the critical point of water $\left(399-409^{\circ} \mathrm{C}\right.$ and $\left.30.8-34.5 \mathrm{MPa}\right)$ with a Ru catalyst. After cooling, the produced gas is burned to support heat for $\mathrm{CHG}$, and the rest of the offgas is cleaned for further applications. The simulation for this process is based on empirical equations.

Gas conditioning processes are required to remove contaminants such as hydrogen sulphide, ammonia, particles, condensates, siloxanes, hydrocarbons, and mercaptanes in the offgas. The conditioned gas can be used to generate $\mathrm{H}_{2}$, heat, and/or power. It is mixed with $\mathrm{NG}$ and superheated steam to generate $\mathrm{CH}_{4}$, which would be converted into syngas via stream reforming. The syngas is then sent to a high-temperature water-gas-shift reactor to increase the $\mathrm{H}_{2}$ concentration. After cooling the syngas, $\mathrm{H}_{2}$ can be separated using PSA. In order to make this system sustainable, a CHP plant that uses the conditioned gas provides heat and electricity for 
the entire system. In addition, a utilities section is added to the simulation to calculate the required water, air, and electricity.

The inputs and products of this HTL process are summarized in Table 8 . The required electricity can be provided from light gas combustion, or imported from the grid if needed. This analysis includes transportation of the residuals (ash and char) as well as transportation, distribution, and storage of the produced renewable diesel fuels.

TABLE 8 Key Inputs, Outputs, and Emissions of the HTL Processes Using Sewage Sludge

Value

\section{Process Inputs ${ }^{a}$}

Hydrogen

$2.7 \mathrm{MJ} / \mathrm{kg} \mathrm{VS}$

\section{Products}

Hydrocarbon fuel

$14 \mathrm{MJ} / \mathrm{kg} \mathrm{VS}$

Light gases

$1.2 \mathrm{MJ} / \mathrm{kg} \mathrm{VS}^{\mathrm{b}}$

Fuel oil

Solid waste (ash and char)

$0.17 \mathrm{MJ} / \mathrm{kg} \mathrm{VS}$

0.65 wet $\mathrm{kg} / \mathrm{kg} \mathrm{VS}$

\section{Internal Light Gas Combustion for Process Heat and Electricity}

\section{Other Emissions}

VOC

$\mathrm{CO}$

$1.9 \mathrm{~g} / \mathrm{kg} \mathrm{VS}$

$\mathrm{NO}_{\mathbf{x}}$ $0.009 \mathrm{~g} / \mathrm{kg}$ VS

$\mathrm{SO}_{\mathbf{x}}$ $15 \mathrm{~g} / \mathrm{kg} \mathrm{VS}$

$\mathrm{CH}_{4}$

${ }^{a}$ Required electricity input $(0.64 \mathrm{MJ} / \mathrm{kg}$ VS) is fully supported by light gas combustion.

${ }^{\mathbf{b}}$ The excess amount of light gases (total light gases produced minus light gases combusted internally) is exported as a coproduct. 


\section{RESULTS AND DISCUSSIONS}

To examine the impact of different WTE scenarios on the WTW GHG emissions, this study considered a Meso-1 AD co-located with a 100-MGD WWTP in Illinois as a counterfactual scenario. Note that results could differ by location and WWTP size. As mentioned earlier, a portion of biogas from $\mathrm{AD}$ in the counterfactual scenario is combusted in a boiler to meet the heat demands for $\mathrm{AD}$ while the remainder of biogas is flared. In the AD-based WTE scenarios, on the other hand, a micro-turbine CHP is used to generate heat and power. Once $\mathrm{RNG}$ is produced, it is assumed to be transmitted to offsite refueling stations through pipelines, and compressed using electric compressors. For HTL, it is assumed that the CHP is used only to support the minimum onsite heat and electricity demand from light gas combustion, and the rest of the products are used as fuels.

Figure 8 shows WTW GHG emissions of the counterfactual scenario, renewable CNG via $A D$, and renewable diesel via HTL from sewage sludge, expressed in terms of dry tons of sludge processed. The GHG emissions of the counterfactual scenario $\left(408 \mathrm{~kg} \mathrm{CO}_{2} \mathrm{e} / \mathrm{dry}\right.$ ton of sludge) consist largely of the GHG emissions from biogas combustion (light blue bar in Figure 8) and the upstream GHG emissions associated with external electricity for AD (yellow bar in Figure 8). In the counterfactual scenario, $55 \%$ of the produced biogas from $\mathrm{AD}$ is combusted in a boiler to support heat required for $\mathrm{AD}$ and the remaining $44 \%$ of the biogas is flared.

In the WTE scenarios, the results show that the Meso-1, Meso-2, Meso-1 (TH), M-M Phase, and HTL cases can reduce WTW GHG emissions by 39\%, 46\%, 63\%, 80\%, and $87 \%$ relative to the counterfactual scenario, respectively. The values for the HTL case in Figure 8 indicate the sum of positive and negative GHG emissions, which are 765 and $-712 \mathrm{~kg} \mathrm{CO} 2 \mathrm{e} / \mathrm{dry}$ ton of sludge, respectively.

Overall, the main driver for the WTW GHG emissions reduction of the renewable fuel production pathways is the credits from the displaced fuels (fossil CNG for renewable CNG and petroleum diesel for HTL diesel, as well as process electricity) and/or fertilizers. For example, $\mathrm{AD}$ assumptions in the counterfactual scenario and Meso- 1 are identical; only the application of biogas differs. In the WTE scenario, biogas is combusted in CHP to generate heat and electricity, while the counterfactual scenario takes external electricity and uses biogas only to support heat. This avoided electricity usage reduces the GHG emissions in the Meso- 1 case by $82 \mathrm{~kg} \mathrm{CO}_{2} \mathrm{e} / \mathrm{dry}$ ton of sludge. The $\mathrm{AD}$ cases only require a small amount of additional external electricity to operate compressors at offsite refueling stations. In addition to the reductions in external electricity, when $1368 \mathrm{MJ}$ of renewable CNG generated from 1 dry ton of sludge through Meso-1 displaces the same amount of fossil CNG, the displaced GHG emissions are estimated at $104 \mathrm{~kg} \mathrm{CO} 2 \mathrm{e} / \mathrm{dry}$ ton of sludge. Note that the displaced GHG emissions are larger than those from renewable $\mathrm{CNG}$ combustion ( $78 \mathrm{~kg} \mathrm{CO}_{2} \mathrm{e} / \mathrm{dry}$ ton of sludge) because the displaced GHG emissions include not only the combustion emissions (PTW, which are the same as the GHG emissions from renewable CNG combustion) but also the upstream emissions of fossil CNG (WTP). 


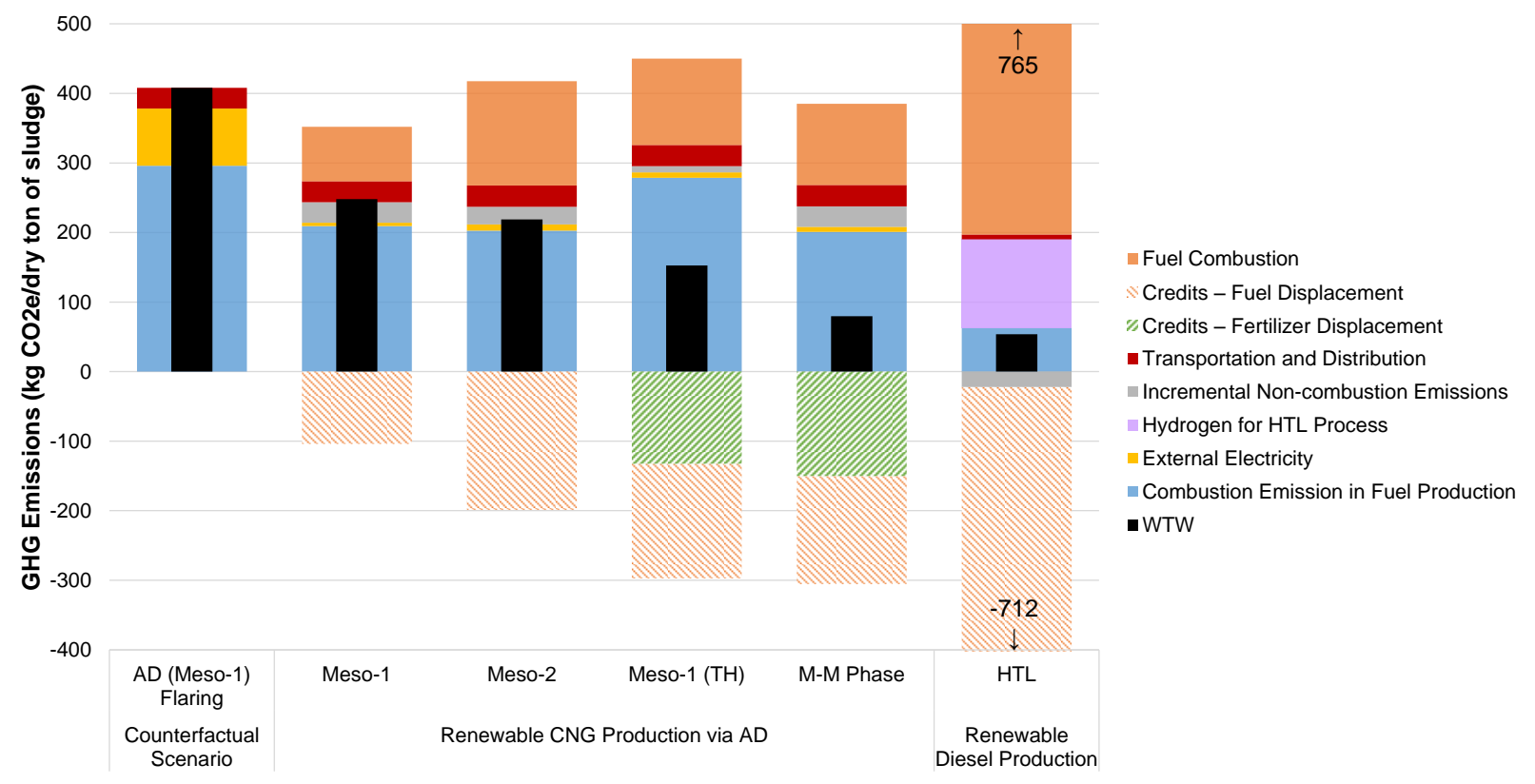

FIGURE 8 WTW GHG Emissions for Renewable CNG from AD and Renewable Diesel from HTL Pathways Produced from Sewage Sludge ( $\mathrm{kg} \mathrm{CO}_{2} \mathrm{e} / \mathrm{dry}$ ton of Sludge Input)

Meso-2 has lower WTW GHG emissions than Meso-1, which results mainly from the larger biogas yield in Meso-2 generating greater GHG emission credits than that of Meso-1. Note that Meso-2 shows slightly lower combustion GHG emissions in the fuel production stage than Meso-1 does, even though Meso-2 is more complex and typically more energy intensive in practice than Meso-1 is. This counterintuitive trend is an artifact of the different modeling approaches we used for Meso-1 and Meso-2. As mentioned earlier, the semi-empirical model is used to estimate the heat and energy requirement of Meso-2. On the other hand, the electricity requirement of Meso- 1 is estimated by the Aspen model, while the heat requirement of Meso-1 is adjusted to be the same as that of Meso- 2 as estimated by the semi-empirical model. To address this inconsistency, a harmonized model needs to be used to examine different $\mathrm{AD}$ technologies.

Compared to Meso-1, Meso-1 (TH) shows much greater combustion emissions during the fuel production stage due to its higher heat and electricity demands for the thermohydrolysis process. However, Meso-1 (TH) produces more biogas than Meso-1, which results in higher GHG reduction benefits from fuel displacement credits. In addition to that, Meso-1 (TH) generates Class A biosolids that are assumed to displace conventional fertilizers. Displacing conventional fertilizers is another large source of GHG emission credits, which accounts for $133 \mathrm{~kg} \mathrm{CO} 2 \mathrm{e} / \mathrm{dry}$ ton of sludge. It should be noted that, if the fertilizer credits are not considered, the GHG emissions of Meso-1 (TH) are slightly higher than those of Meso-1. In other words, the impact on the GHG emissions of biogas yield gains due to thermohydrolysis is largely offset by the increased emissions during fuel production, and the key benefit of thermohydrolysis results from fertilizer displacement.

Among the AD technologies, M-M Phase shows the lowest WTW GHG emissions ( $80 \mathrm{~kg} \mathrm{CO}_{2} \mathrm{e} / \mathrm{dry}$ ton of sludge) because it generates Class A biosolids that displace conventional 
fertilizers and consumes a relatively smaller amount of energy. In particular, the fertilizer displacement credit is estimated at $150 \mathrm{~kg} \mathrm{CO}_{2} \mathrm{e} /$ dry ton of sludge, which is greater than that of Meso-1 (TH). Similar to Meso-1 (TH), M-M Phase WTW GHG emissions are similar to Meso-1 and Meso-2 when the fertilizer credits are excluded.

Based on the results, it is clear that the fertilizer displacement credits are critical for WTW GHG emissions of AD pathways. However, these fertilizer displacement credits were estimated using several assumptions. First, this analysis assumed that nutrients in Class A biosolids fully displace conventional fertilizers by mass. For example, $1 \mathrm{~g}$ of $\mathrm{N}$ in Class $\mathrm{A}$ biosolids is assumed to displace $1 \mathrm{~g}$ of $\mathrm{N}$ in $\mathrm{N}$ fertilizer. In practice, this one-to-one displacement ratio is highly questionable. For example, the nutrient contents of biosolids might be unknown and uncertain. Moreover, even though the same amount of $\mathrm{N}$ is applied to soil, the $\mathrm{N}$ availability from biosolids could be different from that from conventional $\mathrm{N}$ fertilizers. In addition, $\mathrm{N}_{2} \mathrm{O}$ emissions from biosolids and chemical fertilizers are assumed to be the same in this analysis due to insufficient supporting information on this issue. However, considering the high global warming potential of $\mathrm{N}_{2} \mathrm{O}$ emissions, the small differences in $\mathrm{N}_{2} \mathrm{O}$ emission between biosolids and conventional fertilizers may result in significant impacts on fertilizer displacement credits. Thus, due to these uncertainties, further investigation of the fertilizer displacement credits is needed.

The WTP GHG emissions of the HTL case mainly consist of the upstream GHG emissions associated with hydrogen inputs and the light gas combustion (purple and light blue bars in Figure 8, respectively). Because the HTL case utilizes light gas in CHP to generate electricity to support onsite electricity demand, unlike the counterfactual scenario, it does not involve GHG emissions for external electricity, and instead produces emissions from light gas combustion. Note that $11 \%$ of energy products are combusted in CHP for the renewable diesel production pathway. It was found that there are much higher fuel displacement credits and fuel combustion emissions than those of other AD cases. This is because the HTL pathway has much higher fuel conversion efficiency, which results in high fuel yields compared to other AD cases. Therefore, because of its high fuel displacement credits, WTW GHG emissions of the HTL are the lowest among the alternative fuel production pathways.

Non-combustion emissions (gray bars in Figure 8) include largely non-combustion $\mathrm{CH}_{4}$ and $\mathrm{CO}_{2}$ emissions from biogas upgrading and digestate decomposition. Figure 8 shows only marginal changes from the counterfactual scenario for non-combustion emissions to clearly express the differences because both scenarios have a significant amount of non-combustion emissions. It shows that all the alternative AD cases have positive incremental non-combustion emissions; this is because the alternative $\mathrm{AD}$ cases have additional $\mathrm{CH}_{4}$ leakage during biogas upgrading processes, but lower carbon sequestration due to lower digestate production, than the counterfactual case, which leads to positive incremental $\mathrm{CO}_{2}$ emissions. The differences in noncombustion emissions between technologies come from the differences in the amount of biogas and digestate, which vary in $\mathrm{CH}_{4}$ and $\mathrm{CO}_{2}$ emissions. Solid waste generated from the HTL process (i.e., char) has higher carbon sequestration than the counterfactual scenario, and the renewable diesel production pathway via HTL has negative non-combustion emission, correspondingly. 
LCA results expressed in terms of the amount of sludge processed (as in Figure 8) are useful for comparing relative GHG emission impacts between sludge management methods. However, different conversion processes generate different amounts of fuels, even with the same amount of sludge, due to different energy conversion efficiencies. In order to compare the results with other transportation fuels, GHG emissions should be expressed in terms of energy of the fuel (e.g., per MJ of fuel produced and used). The following figures present fossil fuel use and GHG emissions per MJ of fuel. As explained earlier, the marginal analysis considers only relative changes from the counterfactual scenario. Therefore, the GHG emissions and energy use associated with the counterfactual scenario become the credits for the alternative fuel production pathways.

The total GHG emissions per MJ of produced fuels are plotted in Figure 9. WTW GHG emissions from the renewable $\mathrm{CNG}$ production pathway have a negative value $\left(-40 \mathrm{~g} \mathrm{CO}_{2} \mathrm{e} / \mathrm{MJ}\right)$ when Meso-1, the same technology used in the counterfactual scenario, is used. This is because the credits for avoiding the GHG emissions associated with the counterfactual scenario are much higher than those from the GHG emissions generated during fuel production and vehicle operation. GHG emission credits come from avoiding major GHG producers in the counterfactual scenario: biogas flaring, biogas combustion in boilers, and importing electricity.

For the CNG production pathway using Meso-2, GHG emissions are estimated to be $5.3 \mathrm{~g} \mathrm{CO}_{2} \mathrm{e} / \mathrm{MJ}$. Despite the fact that the rest of the conditions are very similar to those of Meso- 1 (i.e., thermal and electric energy requirements), there is a large difference in the GHG emissions on a MJ basis between Meso-1 and Meso-2 results from the biogas yields. With higher biogas yields, less sludge is needed to produce the same amount of fuel. Thus, the credits from the counterfactual scenario become smaller with higher fuel yields when the results are expressed on

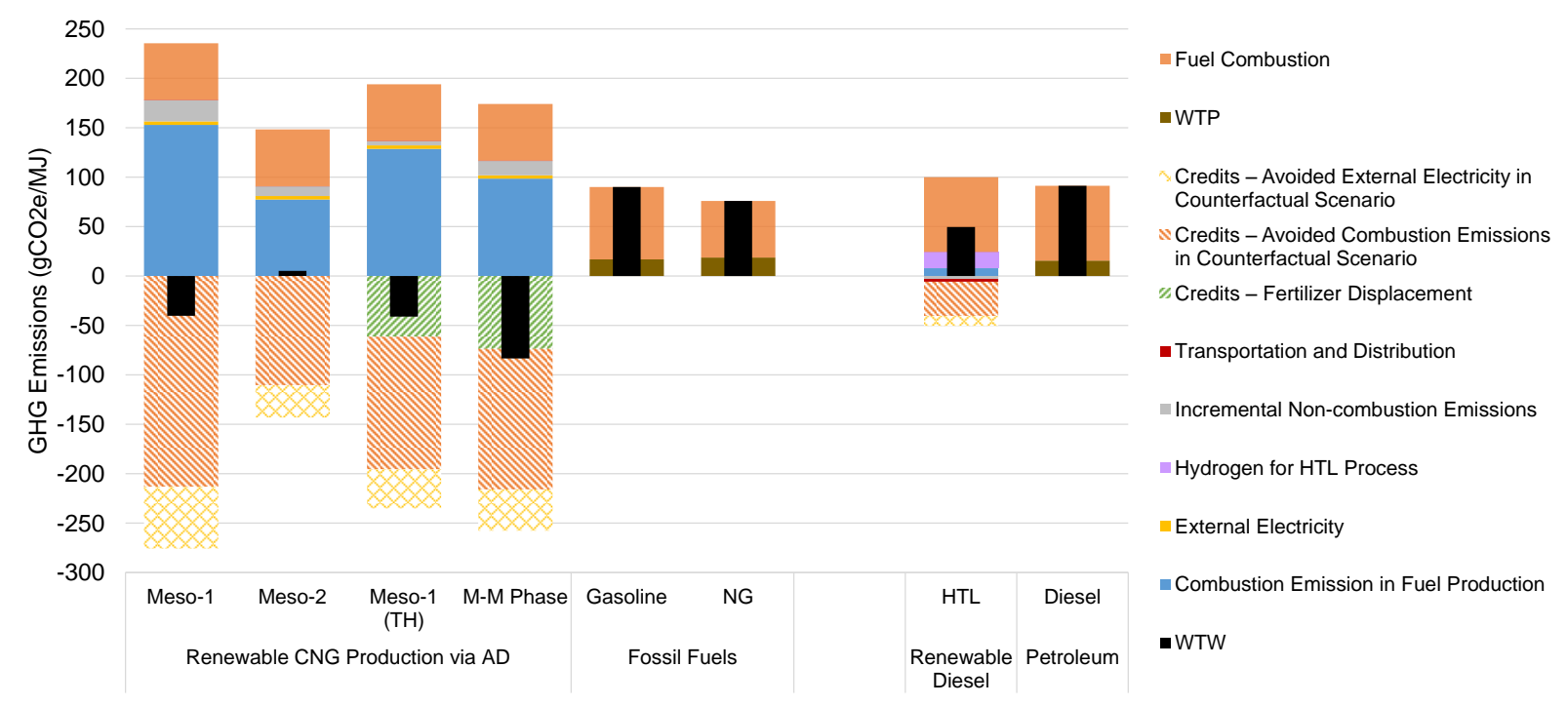

FIGURE 9 WTW GHG Emissions for CNG Produced from Sewage Sludge via AD and Renewable Diesel Produced from HTL Pathways Compared to Conventional NG, Gasoline, and Diesel Pathways (g CO $2 \mathrm{e} / \mathrm{MJ}$ Produced and Used) 
a MJ basis. Moreover, Meso-1 produces a smaller amount of fuel per dry ton of sludge; this amount of fuel is used as a denominator for the per-MJ basis results. Thus, the GHG reductions by Meso- 1 in Figure 8 are exaggerated when they are presented on a MJ basis.

The M-M Phase shows the highest credits, and the WTW GHG emission is estimated to be $-83 \mathrm{~g} \mathrm{CO}_{2} \mathrm{e} / \mathrm{MJ}$ due to additional fertilizer displacement credits. Although Meso-1 (TH) also produces Class A biosolids, its higher biogas yields and energy requirements lead to slightly higher GHG emissions, $-41 \mathrm{gCO}_{2} / \mathrm{MJ}$, than M-M Phase. When the GHG emissions of sludgebased $\mathrm{CNG}$ are compared to those of gasoline, relative changes are $-145 \%,-94 \%,-146 \%$, and $-193 \%$ for the Meso-1, Meso-2, Meso-1 (TH), and M-M Phase, respectively. The HTL pathway produces $50 \mathrm{gCO}_{2} \mathrm{e} / \mathrm{MJ}$ of WTW GHG emissions, which reduces GHG emission by $46 \%$ compared to that of conventional diesel fuels.

Figure 10 shows fossil fuel consumption of renewable CNG from AD and renewable diesel from HTL from sewage sludge, and the results are compared to those of conventional NG, gasoline, and diesel. Similarly, the fossil fuel use of the counterfactual scenario is credited for the alternative fuel production pathways, so that the WTW results can be compared to other transportation fuels. It was found that there is only small amount fossil fuel consumption for the renewable fuel production pathways: external electricity used for offsite NG compression for the $\mathrm{AD}$ cases (blue bars in Figure 10) and fossil fuel consumption associated with the hydrogen production and transportation for the HTL pathway (purple bar in Figure 10). Neither the AD nor the HTL processes involve fossil fuel consumption during vehicle operation because the generated fuels are non-fossil based. The fossil fuel use reduction for the HTL pathway is $91 \%$ compared to diesel fuels, while AD pathways have negative fossil fuel uses. This is one of the most notable benefits of using the alternative fuel production pathways, along with the GHG emission reductions. The major credits come from avoiding the energy consumption associated with the counterfactual scenario for all alternative cases. Unlike the counterfactual scenarios of other RNG pathways studied previously, such as animal waste AD (Han et al. 2011) and landfill gas (LFG) (Mintz et al. 2010), the sewage sludge management currently used as the counterfactual scenario requires external electric energy to support the AD processes, and extra credits can be earned by avoiding this if alternative pathways are used. As explained, digestate of Meso-1 (TH) and M-M Phase displaces fertilizers, which leads to additional credits. Fertilizer displacement credits for $\mathrm{N}, \mathrm{P}_{2} \mathrm{O}_{5}$, and $\mathrm{K}_{2} \mathrm{O}$ are 58, 20, and 7.6 Btu/g fertilizer, respectively, which lead to overall fertilizer displacement credits of 0.9 and 1.1 MJ/MJ of fuel for the Meso-1 (TH) and the M-M Phase, respectively (green bars in Figure 10).

Similar to the GHG emission credits, pathways with higher fuel yields have lower fossil fuel credits. The avoidable fossil fuel consumption for the counterfactual scenario is $1.7 \mathrm{Btu} / \mathrm{g}$ of VS, but the credits per MJ of fuel vary hugely, depending on the conversion efficiency. For example, from $1 \mathrm{~g}$ of VS, only 3.7 Btu of RNG is produced via the Meso-1 (TH) AD pathway, while 13.4 Btu of renewable diesel is produced through the HTL pathways, along with 1.2 and 0.16 Btu of light gas and fuel oil, respectively. The large difference in fuel yields results in different fossil fuel credits between the AD and the HTL processes (yellow bars in Figure 10). 


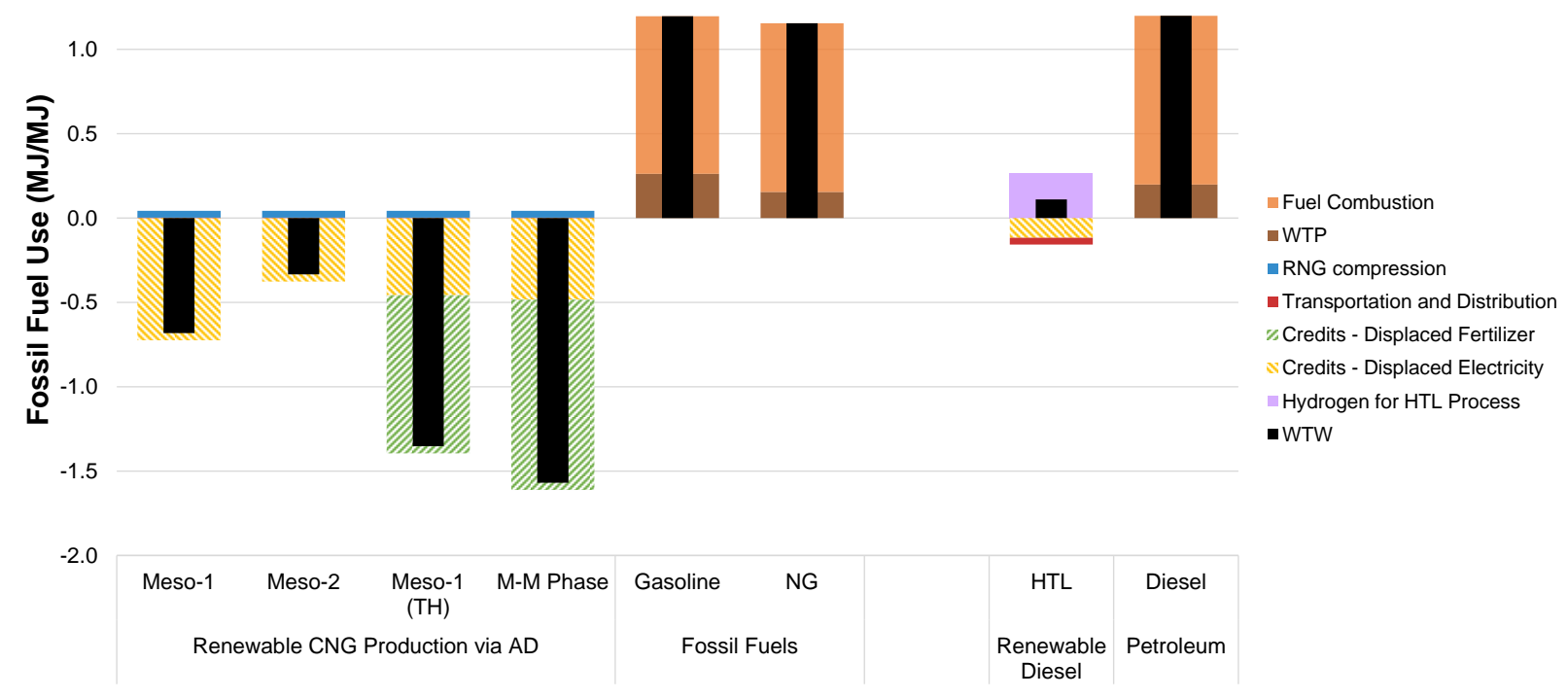

FIGURE 10 WTW Fossil Fuel Use for CNG Produced from Sewage Sludge via AD and Renewable Diesel Produced from HTL Pathways Compared to Conventional NG, Gasoline, and Diesel Pathways (MJ/MJ Produced and Used) 


\section{CONCLUSIONS}

This study performed LCA of sludge-based fuels: $\mathrm{CNG}$ and LNG via $\mathrm{AD}$, and renewable diesel via HTL. Because sewage sludge is regarded as waste material unless it is utilized, incremental energy consumption and GHG emissions have been analyzed compared to current sludge management practices. The most typical sludge treatment, Meso-1 AD with flaring biogas, is set as a counterfactual scenario, and the differences between the alternative and the counterfactual scenario are regarded as benefits or burdens of generating fuels from sewage sludge.

For the AD pathways, four types of AD technologies-Meso-1, Meso-2, Meso-1 (TH), and M-M Phase - from two independent simulation results are used; one simulation uses a semiempirical model and the other uses an Aspen model. For HTL pathways, the same Meso-1 AD without energy recovery is selected as a counterfactual scenario. An Aspen model is also used to simulate renewable diesel production from sewage sludge via HTL processes.

It has been found that the LCA results highly depend on functional units. First, GHG emissions are expressed in terms of dry tons of sludge treated in order to compare the results between sludge treatment methods. The results show that renewable CNG production via $\mathrm{AD}$ cases reduce GHG emissions from $39 \%$ to $80 \%$, and renewable diesel production via HTL case reduces $87 \%$, compared to the counterfactual case, Meso-1 with biogas flaring. Because higher fuel yields produce larger fuel displacement credits, alternative fuel production cases with higher yields show more reductions in GHG emissions in general. Meso-1 (TH) and M-M Phase have much lower WTW GHG emissions compared to other AD technologies due to additional fertilizer displacement credits from Class A biosolids.

In order to compare the WTW GHG emissions with other transportation fuels, the results have been expressed in terms of energy in fuels, and the emissions associated with the counterfactual scenario are credited for the renewable fuel production pathways. In this case, GHG emission credits from the counterfactual scenario become larger when the fuel conversion efficiency is low. This is because cases with lower yields require more sludge to generate the same amount of energy, which leads to higher credits by avoiding more emissions from the counterfactual scenario. Fertilizer displacement credits also influence WTW GHG emissions a great deal, and the credits mostly surpass other combustion and non-combustion emissions. When the results are compared to the GHG emissions of gasoline, relative changes of sludgebased CNG ranged from -94\% to -193\%, depending on the type of AD technology. Renewable diesel from sewage sludge via HTL also reduces WTW GHG emissions by $46 \%$ compared to those of diesel fuel.

It is important to note that the LCAs using waste feedstocks are closely related to both the counterfactual scenarios that are conventional ways of managing waste and the alternative fuel production pathways. Thus, defining a proper counterfactual case that reflects the current waste management practice is critically important. In addition, the functional unit for LCA is also important for numerical LCA results. Note that the counterfactual scenario in this study assumed that biogas is flared because many WWTPs with AD currently do not recover energy from 
biogas. However, according to the EPA, a substantial increase in D3 RIN generation from biogas has observed after the EPA allowed biogas for D3 RIN. Thus, in the future, the counterfactual scenario may need to be modified to include a certain share of energy recovery from biogas if the trend of the sewage sludge treatment technologies shows a continuous increase of energy recovery from biogas or varies over time as a result of changes in regulations or economic conditions. In addition, despite the importance of fertilizer displacement credits, this analysis relies on assumptions because limited information is available on biosolids applications to displace fertilizer. Differences in crop yields and $\mathrm{N}_{2} \mathrm{O}$ emissions between the biosolids and chemical fertilizers need to be investigated further to refine the fertilizer displacement credits. 


\section{ACKNOWLEDGEMENT}

This research effort by Argonne National Laboratory was supported by the Bioenergy Technology Office (BETO) of the Office of Energy Efficiency and Renewable Energy of the U.S. Department of Energy under contract DE-AC02-06CH11357. We are grateful to Daniel Fishman, Mark Philbrick, and Brandon Hoffman of BETO for their support and guidance. We gratefully acknowledge Brian Helmowski of the California Department of Resources Recycling and Recovery, and the support and technical input drawn from his comments on an earlier draft of the report. 


\section{REFERENCES}

Argonne (Argonne National Laboratory), 2015. Greenhouse gases, Regulated Emissions, and Energy use in Transportation (GREET) Model.

Beecher, N., Crawford, K., Goldstein, N., Kester, G., Lono-Batura, M., Dziezyk, E., 2007. A national biosolids regulation, quality, end use and disposal survey. Tamworth, NH, North East Biosolids Residuals Assoc.

Börjesson, P., Berglund, M., 2006. Environmental systems analysis of biogas systems-Part I: Fuel-cycle emissions. Biomass Bioenergy 30, 469-485. doi:10.1016/j.biombioe.2005.11.014

Brown, S., Beecher, N., Carpenter, A., 2010. Calculator tool for determining greenhouse gas emissions for biosolids processing and end use. Environmental Science \& Technology 44, 95099515.

Brown, S., Tian, G., Cox, A., Collins, D., 2012. A greenouse gas accounting of the metropolitan water reclamation district of greater Chicago's biosolids end uses: Evaluation of years 2001 and 2008.

California Energy Commission, 2005. California’s Water-Energy Relationship: Final Staff Report. California Energy Commission.

California Sustainability Alliance, 2008. The role of recycled water in energy efficiency and greenhouse gas reduction.

Code of Federal Regulations (CFR): Title 40: Protection of Environment, Part 80-Regulation of Fuels and Fuel Additives, 2014.

Code of Federal Regulations (CFR): Title 40: Protection of Environment, Part 503-Standards for the use of disposal of sewage sludge, Subpart B-Land Application, 1999.

Cooley, H., Wilkinson, R., Heberger, M., Allen, L., Gleick, P.H., Nuding, A., 2012. Implications of future water supply sources for energy demands. Alexandria. VA. WaterReuse Research Foundation.

Daelman, M.R., van Voorthuizen, E.M., van Dongen, U.G., Volcke, E.I., van Loosdrecht, M.C., 2012. Methane emission during municipal wastewater treatment. Water Research. 46, 36573670 .

De Haas, D., Foley, J., Lant, P., 2009. Energy and greenhouse footprints of wastewater treatment plants in south-east Queensland. Australia. Australian Water Association. 
Del Borghi, A., Converti, A., Palazzi, E., Del Borghi, M., 1999. Hydrolysis and thermophilic anaerobic digestion of sewage sludge and organic fraction of municipal solid waste. Bioprocess Engineering 20, 553-560.

Dieterich, B., Finnan, J., Frost, P., Gilkinson, S., Müller, C., 2012. The extent of methane (CH4) emissions after fertilisation of grassland with digestate. Biology and Fertility of Soils 48, 981985. doi:10.1007/s00374-012-0714-1

ECONorthwest, 2011. Embedded energy in water pilot programs impact evaluation. Portland, OR.

Environmental Research Information Center. 1978. Sludge treatment and disposal (No. EPA 625/4-78-012; EPA 625/4-78-012A; EPA 625/4-78-012B). Environmental Protection Agency, Technology Transfer, Cincinnati, $\mathrm{OH}$.

EPA (U.S. Environmental Protection Agency), 1978. Total Energy use for Municipal Wastewater Treatment (No. EPA-600/2-78-149). Cincinnati, OH.

EPA, 1999. Biosolids generation, use and disposal in the United States (No. EPA 530-R-99-009). Washington, DC.

EPA, 2006a. Emerging Technologies for Biosolids Management (No. EPA 832-R-06-005). Washington, DC.

EPA, 2006b. Biosolids Technology Fact Sheet: Multi-Stage Anaerobic Digestion (No. EPA 832F-06-031). Washington, DC.

EPA, 2008. Ensuring a Sustainable Future: AN Energy Management Guidebook for Wastewater and Water Utilities (No. 832R08002). Washington, DC.

EPA, 2011. Opportunities for Combined Heat and Power at Wastewater Treatment Facilities: Market Analysis and Lessons from the Field (No. 430R11018). Washington, DC.

EPA, 2015. Advancing Sustainable Materials Management: 2013 Fact Sheet (No. EPA 530-R15-003). Washington, DC.

EPA, 2016a. Inventory of U.S. Greenhouse Gas Emissions and Sinks (No. EPA 430-R-16-002). Washington, DC.

EPA, 2016b. Clean Watersheds Needs Survey (CWNS) - 2012 Report and Data (No. EPA 830R-15005). Washington, DC.

EPRI (Electric Power Research Institute), 1996. Water and Wastewater Industries: Characteristics and Energy Management Opportunities (No. CR-106941). Palo Alto, CA. 
Foley, J., Lant, P.A., 2009. Direct Methane and Nitrous Oxide emissions from full-scale wastewater treatment systems. Australia. Australian Water Association.

Ghazy, M.R., Dockhorn, T., Dichtl, N., 2011. Economic and environmental assessment of sewage sludge treatment processes application in International Water Technology Journal 1, 117.

Gray, D.M., Suto, P., Peck, C., 2008. Anaerobic digestion of food waste. East Bay Municipal Utility District.

Han, J., Mintz, M., Wang, M., 2011. Waste-to-wheel analysis of anaerobic-digestion-based renewable natural gas pathways with the GREET model (No. ANL/ESD/11-6). Argonne National Laboratory.

Harrison, J.R., Goodson, J.B., Culp, G., Smith Jr, J.E., Dyer, J.C., 1974. Process Design Manual for Sludge Treatment and Disposal. EPA. 625, 1-74.

Heidrich, E.S., Curtis, T.P., Dolfing, J., 2010. Determination of the internal chemical energy of wastewater. Environmental Science \& Technology 45, 827-832.

Inoue, S., Sawayama, S., Ogi, T., Yokoyama, S., 1996. Organic composition of liquidized sewage sludge. Biomass Bioenergy 10, 37-40.

Jones, S., Meyer, P., Snowden-Swan, L., Padmaperuma, A., Tan, E., Dutta, A., Jacobson, J., Cafferty, K., 2013. Process design and economics for the conversion of lignocellulosic biomass to hydrocarbon fuels: fast pyrolysis and hydrotreating bio-oil pathway. National Renewable Energy Laboratory (NREL), Golden, CO.

Kalogo, Y., Bagley, D.M., Monteith, H.D., 2005. Steady state model to predict volatile solids reduction in anaerobic digestion. Proceedings of the Water Environment Federation. 2005, 44814495. doi:10.2175/193864705783866702

Kim, S.-H., Han, S.-K., Shin, H.-S., 2004. Feasibility of biohydrogen production by anaerobic co-digestion of food waste and sewage sludge. International Journal of Hydrogen Energy 29, $1607-1616$.

Kunetz, T.E., Fink-Finowicki, J., McGowan, S., Auerbach, E., 2012. Development of a comprehensive plan for utilization of digester gas moves towards energy self-sufficiency in Chicago, USA. Water Science \& Technology 66, 95-104.

Lemoine, F., Maupin, I., Lemée, L., Lavoie, J.-M., Lemberton, J.-L., Pouilloux, Y., Pinard, L., 2013. Alternative fuel production by catalytic hydroliquefaction of solid municipal wastes, primary sludges and microalgae. Bioresource Technology 142, 1-8.

Maas, C., 2009. Greenhouse gas and energy co-benefits of water conservation. POLIS Project on Ecological Governance. 
Mintz, M., Han, J., Wang, M., Saricks, C., 2010. Well-to-Wheels analysis of landfill gas-based pathways and their addition to the GREET model (No. ANL/ESD/10-3). Argonne National Laboratory.

Møller, J., Boldrin, A., Christensen, T.H., 2009. Anaerobic digestion and digestate use: accounting of greenhouse gases and global warming contribution. Waste Management \& Research 27, 813-824. doi:10.1177/0734242X09344876

Monteith, H., Bagley, M.D., MacLean, M.H., Kalogo, Y., 2006. An assessment tool for managing cost-effective energy recovery from anaerobically digested wastewater solids. Water Environment Research Foundation. Alexandria. VA.

Mosher, B.W., Czepiel, P.M., Harriss, R.C., Shorter, J.H., Kolb, C.E., McManus, J.B., Allwine, E., Lamb, B.K., 1999. Methane Emissions at Nine Landfill Sites in the Northeastern United States. Environmental Science \& Technology 33, 2088-2094. doi:10.1021/es981044z

Moss, L.H., Carr, J.S., Donovan, J.F., Parry, D.L., Tsang, K.R., Greenwood, R., Wheless, A., 2011. Charting the Future of Biosolids Management - Final Report. Water Environment Federation. URL http://www.wef.org/CFBM_FinalReport.

Moss, L.H., Donovan, J.F., Carr, S., Stone, L., Polo, C., 2013. Enabling the Future: Advancing Resource Recovery from Biosolids. Water Environment Federation. URL http://www.wef.org/uploadedFiles/Biosolids/PDFs/ENABLING\%20THE\%20FUTURE.pdf.

Navigant Consulting, 2006. Refining Estimates of Water-related Energy Use in California (No. CEC-500-2006-118). Sacramento, CA.

NCDC (National Climatic Data Center) [WWW Document] Climate at a Glance, 2012. URL http://www.ncdc.noaa.gov/cag/

Pacific Gas \& Electric Company, 2007. Supply and demand side water-energy efficiency opportunities - Final Report. Santa Rosa, CA. URL http://www.allianceforwaterefficiency.org/WorkArea/DownloadAsset.aspx?id=2262.

Parnaudeau, V., Nicolardot, B., Pagès, J., 2004. Relevance of organic matter fractions as predictors of wastewater sludge mineralization in soil. Journal of Environmental Quality 33, $1885-1894$.

Pertl, A., Mostbauer, P., Obersteiner, G., 2010. Climate balance of biogas upgrading systems. Waste Management 30, 92-99. doi:10.1016/j.wasman.2009.08.011

Ruggeri, B., Bernardi, M., Tommasi, T., 2012. On the pre-treatment of municipal organic waste towards fuel production: a review. International Journal of Environment and Pollution 49, 226250 . 
Sanscartier, D., MacLean, H.L., Saville, B., 2012. Electricity Production from Anaerobic Digestion of Household Organic Waste in Ontario: Techno-Economic and GHG Emission Analyses. Environmental Science \& Technology 46, 1233-1242. doi:10.1021/es2016268

Sauer, P., Kimber, A., 2002. Energy consumption and costs to treat water and wastewater in Iowa.

Sosnowski, P., Wieczorek, A., Ledakowicz, S., 2003. Anaerobic co-digestion of sewage sludge and organic fraction of municipal solid wastes. Advances in Environmental Research 7, 609616.

Tchobanoglous, G., Stensel, H.D., Tsuchihashi, R., Burton, F., Abu-Orf, M., Bowden, G., Pfrang, W., 2013. Wastewater Engineering: Treatment and Resource Recovery, 5th edition. McGraw-Hill Education, New York, NY.

Tchobanoglous, G., Theisen, H., Vigil, S., 1993. Integrated solid waste management: engineering principles and management issues. McGraw-Hill, Inc.

Toonssen, R., Aravind, P.V., Smit, G., Woudstra, N., Verkooijen, A.H.M., 2010. System study on hydrothermal gasification combined with a hybrid solid oxide fuel cell gas turbine. Fuel Cells $10,643-653$.

Vavouraki, A.I., Angelis, E.M., Kornaros, M., 2013. Optimization of thermo-chemical hydrolysis of kitchen wastes. Waste Management 33, 740-745.

Wagland, S.T., Godley, A.R., Tyrrel, S.F., 2011. Investigation of the application of an enzymebased biodegradability test method to a municipal solid waste biodrying process. Waste Management 31, 1467-1471.

Wang, L.K., Shammas, N.K., Hung, Y.-T. (Eds.), 2007. Biosolids Treatment Processes: Volume 6, 2007 edition. Humana Press, Totowa, N.J.

Wang, Z., 2011. Reaction mechanisms of hydrothermal liquefaction of model compounds and biowaste feedstocks. University of Illinois at Urbana-Champaign.

WEF (Water Environment Federation), 2009. Energy Conservation in Water and Wastewater Facilities - MOP 32, 1 edition. McGraw-Hill Professional, Alexandria, VA: New York.

WEF, 2013. Biogas production and use at water resource recovery facilities in the United States. Alexandria, VA. URL http://www.casaweb.org/documents/8-5-2013_wefphase1_biogas_data_results.pdf.

WERF (Water Environment Research Foundation), 2010. Annual Report. Alexandria, VA. 
Xu, Z.R., Zhu, W., Gong, M., Zhang, H.W., 2013. Direct gasification of dewatered sewage sludge in supercritical water. Part 1: Effects of alkali salts. International Journal of Hydrogen Energy 38, 3963-3972.

Yong, T.L.-K., Matsumura, Y., 2012. Reaction kinetics of the lignin conversion in supercritical water. Industrial \& Engineering Chemistry Research 51, 11975-11988.

Yong, T.L.-K., Matsumura, Y., 2013. Kinetic analysis of lignin hydrothermal conversion in suband supercritical water. Industrial \& Engineering Chemistry Research 52, 5626-5639.

Yoshida, H., Christensen, T.H., Scheutz, C., 2013. Life cycle assessment of sewage sludge management: A review. Waste Management \& Research 31, 1083-1101.

Zhao, L., Wang, X.-Y., Gu, W.-M., Shao, L.-M., He, P.-J., 2011. Distribution of C and N in soluble fractionations for characterizing the respective biodegradation of sludge and bulking agents. Bioresource Technology 102, 10745-10749.

Zwart, K.B., Kuikman, P.J., 2011. Co-digestion of animal manure and maize: is it sustainable?an update (No. 2169). Alterra. Wageningen, Netherlands. 
APPENDIX A 


\section{APPENDIX A}

TABLE A1 The Parametric Assumptions for AD Technologies

\begin{tabular}{|c|c|c|c|c|c|c|c|c|c|c|c|c|}
\hline \multirow[b]{3}{*}{ Parameter } & \multirow{2}{*}{\multicolumn{8}{|c|}{ Semi-Empirical }} & \multicolumn{4}{|c|}{ Aspen Model } \\
\hline & & & & & & & & & \multicolumn{2}{|c|}{ Baseline } & \multicolumn{2}{|c|}{ Conservative } \\
\hline & $\begin{array}{c}\text { Meso- } \\
1 \\
\end{array}$ & $\begin{array}{l}\text { Meso- } \\
2 \\
\end{array}$ & $\begin{array}{l}\text { M-M } \\
\text { Phase }\end{array}$ & $\begin{array}{c}\text { M-T } \\
\text { Phase }\end{array}$ & $\begin{array}{c}\text { Termo- } \\
1 \\
\end{array}$ & $\begin{array}{l}\text { Thermo- } \\
2\end{array}$ & $\begin{array}{c}\text { M-T } \\
\text { TPAD }\end{array}$ & $\begin{array}{c}\mathrm{T}-\mathrm{M} \\
\mathrm{TPAD}\end{array}$ & $\begin{array}{c}\text { Meso- } \\
1 \\
\end{array}$ & $\begin{array}{c}\text { Meso- } \\
1, \mathrm{TH} \\
\end{array}$ & $\begin{array}{c}\text { Meso- } \\
1 \\
\end{array}$ & $\begin{array}{r}\text { Meso- } \\
1, \text { TH } \\
\end{array}$ \\
\hline $\begin{array}{l}\text { Volatile solid reduction } \\
\text { (VSR, \%) }\end{array}$ & $50 \%$ & $56 \%$ & $50 \%$ & $61 \%$ & $57 \%$ & $65 \%$ & $62 \%$ & $56 \%$ & $45 \%$ & $64 \%$ & $31 \%$ & $43 \%$ \\
\hline $\begin{array}{l}\text { Total electrical energy requirement } \\
(\mathrm{MJ} / \mathrm{kg} \text { VS) }\end{array}$ & 0.37 & 0.37 & 0.37 & 0.29 & 0.25 & 0.25 & 0.37 & 0.37 & 0.55 & 1.3 & 0.46 & 1.1 \\
\hline $\begin{array}{l}\text { Baseline thermal energy requirement } \\
(\mathrm{MJ} / \mathrm{kg} \mathrm{VS})\end{array}$ & 0.75 & 0.75 & 0.75 & 3.0 & 2.4 & 2.4 & 4.3 & 2.4 & 0.83 & & 0.83 & \\
\hline $\begin{array}{l}\text { AD operating temperature } \\
\left({ }^{\circ} \mathrm{C}\right)\end{array}$ & 35 & 35 & 35 & 50 & 55 & 55 & 40 & 55 & 35 & & 35 & \\
\hline$\alpha$ & 0.128 & 0.128 & 0.128 & 0.127 & 0.127 & 0.127 & 0.128 & 0.127 & 0.128 & & 0.128 & \\
\hline$\beta$ & 0.208 & 0.208 & 0.208 & 0.180 & 0.159 & 0.159 & 0.208 & 0.005 & 0.208 & & 0.208 & \\
\hline $\begin{array}{l}\text { AD specific thermal energy requirement } \\
(\mathrm{MJ} / \mathrm{kg} \text { VS degree } \mathrm{C})\end{array}$ & 0.14 & 0.14 & 0.14 & 0.14 & 0.14 & 0.14 & 0.14 & 0.13 & 0.14 & & 0.14 & \\
\hline $\begin{array}{l}\text { Marginal thermal energy requirement } \\
(\mathrm{MJ} / \mathrm{kg} \mathrm{VS})\end{array}$ & 3.3 & 3.3 & 3.3 & 5.4 & 6.0 & 6.0 & 4.0 & 5.7 & 3.3 & & 3.3 & \\
\hline $\begin{array}{l}\text { Total thermal energy requirement } \\
(\mathrm{MJ} / \mathrm{kg} \mathrm{VS})\end{array}$ & 4.1 & 4.1 & 4.1 & 8.4 & 8.4 & 8.4 & 8.3 & 8.1 & 4.1 & 5.1 & 4.1 & 5.1 \\
\hline Digestate Class by EPA & $\mathrm{B}$ & B & A & A & A & A & A & A & $\mathrm{B}$ & A & $\mathrm{B}$ & A \\
\hline
\end{tabular}


APPENDIX B 


\section{APPENDIX B}

\section{WASTEWATER COLLECTION AND WWTP}

The electricity consumption for wastewater collection has been collected from the literature. This consumption varies from 140 to $440 \mathrm{kWh} / \mathrm{MG}$, with a median value of 280 kWh/MG (California Energy Commission 2005; California Sustainability Alliance 2008; Cooley et al. 2012; ECONorthwest 2011; Maas 2009; Navigant Consulting 2006; Pacific Gas \& Electric Company 2007; Sauer and Kimber 2002). Energy consumption in waste-water treatment plants (WWTPs) is generally in the form of electricity and depends largely on average flow rates and treatment processes. One of the first estimates of electrical intensity of wastewater treatment by the U.S. Environmental Protection Agency (EPA) in 1978 showed a range from 2,300 to $3,700 \mathrm{kWh} / \mathrm{MG}$ (EPA 1978). The estimates have since been reduced to around 1,750 kWh/MG in subsequent reports by the Electric Power Research Institute (EPRI) and the EPA (EPRI 1996; EPA 2008). Recently, the Water Environment Federation (WEF) published energy intensity values for various types of WWTPs; these findings are summarized in Table B1 (WEF 2009). The electricity intensity decreases as the plant size increases, and increases with more advanced treatment.

TABLE B1 Estimates of Average Electric Energy Intensity (kWh/MG) of Various Wastewater Treatment Facilities (WEF 2009)

\begin{tabular}{lrrrrrr}
\hline & \multicolumn{7}{c}{ Average Flow (MGD) } \\
\cline { 2 - 7 } \multicolumn{1}{c}{ Treatment Plant } & \multicolumn{1}{c}{1} & 5 & 10 & 20 & 50 & 100 \\
\hline & 1,811 & 978 & 852 & 750 & 687 & 673 \\
Trickling filter & 2,236 & 1,369 & 1,203 & 1,114 & 1,051 & 1,028 \\
Activated sludge & 2,596 & 1,573 & 1,408 & 1,303 & 1,216 & 1,188 \\
Advanced treatment without nitrification & 2,951 & 1,926 & 1,791 & 1,676 & 1,588 & 1,588 \\
Advanced treatment with nitrification & & & & &
\end{tabular}





\section{Argonne}

\section{Energy Systems Division}

9700 South Cass Avenue, Bldg. 362

Argonne, IL 60439-4854

www.anl.gov 